\title{
Skill Demands in the Audit Labor Market: Evidence from Job Postings
}

\begin{abstract}
This study examines how the demand for auditor skill sets has changed over the past decade as well as how these changes relate to audit quality and audit fees. Using a novel dataset that contains the near-universe of online job postings by accounting firms from 2007 to 2017, we find that audit firms have decreased their demand for auditors and increased their demand for IT-related personnel. We also find that audit firms are increasingly demanding expanded skill sets from their auditors - the portion of cognitive, social, and IT-related skills has increased over our sample period whereas financial skills have remained relatively flat. Further, we find substantial variation in the demand for skills not only across audit firms, but also across offices within an audit firm. More importantly, these differences in skill requirements have a significant effect on audit quality - specifically, audit offices that demand more social and cognitive skills are less likely to have clients experience subsequent restatements. Taken together, our findings provide new insights on the changing dynamics of the auditor labor market and their relations to audit quality.
\end{abstract}




\section{Introduction}

The emergence of new technologies is redefining labor markets across all industries. Routinebased tasks that employees were typically responsible for are increasingly being completed by computers, artificial intelligence, and machine learning algorithms (e.g., Levy and Murnane 2012; Brynjolfsson and McAfee, 2014; Remus and Levy 2016). Given the growing prevalence of these disruptive technologies and their influence on the competitive landscape, firms are responding by demanding labor that can complement and deploy them (e.g., Deming 2017; Deming and Kahn 2018). The audit industry is no exception. With innovations in big data, analytics, and distributed ledger technologies (blockchain), how audits are conducted is evolving rapidly and auditors are expected to possess the necessary skills to keep pace with these changes. However, we know little about how these forces have shaped the audit profession in recent years, beyond anecdotal and survey evidence. In this study, we exploit a unique and nearly comprehensive dataset of online job postings by accounting firms in the US from 2007 to 2017 to provide the first large sample evidence on how the auditing labor market has evolved over this time. Specifically, we address three core research questions over our sample period: 1) How has the demand for auditors and non-auditor information technology (IT) staff changed? 2) How has the demand for auditor skill sets changed? 3) How have these shifts in demand affected audit quality?

Understanding how recent changes in technology have impacted the auditing labor market, and ultimately audit quality, is both timely and relevant. The audit industry has invested heavily in emerging technologies and it remains unclear how these investments affect auditors. In recent years, accounting firms have spent approximately $\$ 3$ to $\$ 5$ billion annually on technology (PCAOB 2017a). ${ }^{1}$ Whether audit firms can effectively utilize new technological tools to enhance audit quality hinges critically on the adaptability of their auditors-i.e., whether auditors have the relevant skills to

\footnotetext{
${ }^{1}$ Ernst \& Young recently announced a plan to invest $\$ 1$ billion as part of its innovation drive where a primary goal of these investments is to improve audit quality (EY 2018).
} 
implement and effectively integrate new technologies into the audit process (CAQ 2018). As Roshan Ramlukan, an EY partner and a leader in global assurance analytics, nicely summarized, "the human element of data analytics is the most critical factor" in this data-driven digital era (Tschakert and Kozlowski, 2016). The PCAOB has expressed similar sentiments:

The emergence and use of new technologies in the audit will require professional skepticism and critical thinking by auditors in new ways. These technology tools and approaches may also highlight the need for stronger skills in more subjective and qualitative areas, as auditors learn to work with data and technology in new ways. (PCAOB 2017b)

Therefore, it is important to gain a better understanding of how the demand for auditors and their skillsets have changed in recent years.

We address our research questions by exploiting a novel dataset of job vacancies from Burning Glass Technologies (BG) that includes nearly all online job postings in the US from 2007 to 2017. This is a relatively new and rich data set that has been used by labor economists to capture skill demands for professionals in various occupations (Deming and Kahn 2018; Hershbein and Kahn 2018). ${ }^{2}$ Each job post in the dataset contains approximately 70 standardized fields, including detailed information on the employer, occupation, job location, as well as skill, education, and experience requirements. The granular job posting data thus allow us to capture how the demand for auditor skills has changed over time as well as how it varies across audit firms and within firms across different office locations. Our sample, which focuses on the audit industry, includes over 500,000 job posts over our sample period for 107 unique audit firms.

We begin by providing descriptive evidence on how the mix of job types demanded by audit firms has changed over our sample period. We find that, among all the job postings by audit firms, while the percentage of audit positions has gradually decreased, the percentage of IT positions has gradually increased over our sample period. In particular, the percentage of audit positions was $22 \%$

\footnotetext{
${ }^{2}$ For instance, Hershbein and Kahn (2018) use the BG data to study how the Great Recession altered firms' demand for routine-based jobs. They perform useful validity checks by comparing the BG data to other data sources that list job vacancies at an industry-level or occupation-level, such as the Job Openings and Labor Turnover Survey and the Current Population Survey.
} 
in 2007 , decreased to $14 \%$ in 2012 , and dropped further to $7 \%$ in 2017 . In contrast, the percentage of IT positions was $3 \%$ in 2007, increased to $11 \%$ in 2012, and went further up to $21 \%$ in 2017 . We also demonstrate the increase in IT jobs was driven almost entirely by the Big 4 whereas the decline in audit jobs was muted, but still present, for the Big $4 .{ }^{3}$ These findings suggest that Big 4 accounting firms are not only investing financially into technology, but also changing the composition of their workforce to adopt to the evolving technologies.

We then turn to our main analysis and examine the skills demanded for the subset of audit positions. Specifically, we focus on three skill categories: technology skills, cognitive skills, and social skills. We choose these skill requirements for several reasons. First, prior research in the economics literature has focused on these skills when studying the impact of technological development on professional jobs (Autor, Levy, and Murnane 2003; Brynjolfsson and McAfee 2011). Second, these are important skills for those in the auditing profession. It has been widely reported that technology skills are becoming necessary for auditors and that, as computers complete more routine tasks, auditors will focus more on complex tasks that require cognitive and social skills (e.g., Davenport and Raphael 2017). We additionally incorporate financial skills given the importance of these skills for auditors.

We first provide descriptive evidence on the time-series variation in the skills demanded of audit personnel. We find a significant increase in the number of skills demanded for audit personnel, consistent with upskilling in the aftermath of the great recession (Hershbein and Kahn 2018). We also find that jobs posted by Big 4 firms demand more skills relative to non-Big 4 firms, as do jobs posted for more senior auditors. With respect to the mix of skills demanded, we find the percentage of financerelated skills remains relatively flat over the sample period while cognitive, social, and IT-related skills all increase as a fraction of total skills. These findings are consistent with the assertions that auditors will need to possess greater qualitative skills to complement the increases in technological skills.

\footnotetext{
${ }^{3}$ These results hold after we control for audit firm or audit office fixed effects.
} 
We then show that there is substantial heterogeneity in the demand for job skills, even within firm, location, and year, and when controlling for job characteristics such as seniority as well as education and experience requirements. As expected, there is systematic variation, both across audit firms and audit offices, in the amount and type of skills demanded. However, much variation remains even after controlling for an extensive set of controls. At the office-level this residual variance ranges between 30 and $60 \%$ (depending on the skill type), suggesting that audit offices have considerable discretion in the types of skills they demand for audit personnel.

Next, we examine whether the demand for certain skill sets is associated with audit quality. Given the discretion in skill demands afforded to audit offices, we aggregate job posts at the audit office level and capture the average number of skills per job demanded within the audit office. To proxy for audit quality, we examine future restatements of the clients audited by the corresponding audit office. We find the average number of total skills posted per job is negatively correlated with future restatements, consistent with more skilled auditors providing higher quality audits. Interestingly, this finding is driven primarily by the demand for cognitive and social skills, which suggests that despite the growing importance of technologies in the profession, cognitive and social skills remain an important skillset for auditors.

Finally, we examine how the skills sets of audit personnel correlate with audit fees. On the one hand, auditors with more skills are presumably of higher quality than auditors with fewer skills. Higher quality auditors may demand higher wages, which could be passed on to the client, resulting in higher audit fees. On the other hand, higher quality auditors may be more efficient in performing audit tasks, which could result in less time billed to the client and thus lower fees. Our results suggest that audit offices with higher skilled auditors charge lower audit fees relative to audit offices with lower skilled auditors, and this effect is predominantly driven by cognitive skills.

Our study makes several contributions to the literature. First, a large audit literature examines how various factors such as industry specialization and Big $\mathrm{N}$ office size affect audit quality (e.g., 
Francis and Yu 2009; Reichelt and Wang 2010). However, there is scant research on how auditor attributes affect audit quality. Indeed, a survey by Defond and Zhang (2014) calls for more research to explore how different dimensions of auditor competencies, including the traits of individual auditors, affect audit quality. Our study adds to this literature by studying the specific skills demanded by audit firms. Further, our study complements recent research that exploits detailed proprietary audit input data such as audit hours from the PCAOB to study the link between audit inputs and audit quality (Aobdia, Siddiqui, and Vinelli 2018; Abodia, Choudhary, and Newberger 2018; Gipper, Hail, and Leuz 2019) by introducing auditor skills as another input that can affect audit quality.

Second, to our knowledge, our study is the first to examine how the era of emerging technologies has reshaped human capital requirements in the audit industry. While emerging technologies are undoubtedly disrupting various dimensions of the audit process (PCAOB 2017a; AICPA 2017b), there is little empirical evidence on this topic-extant research is predominantly normative or small-scale surveys (e.g., Lowe et al. 2017). Our study adds to this stream of research by providing large sample evidence on how the demand for auditor skill sets has evolved and how this shift in demand affects audit quality.

Third, our study complements the growing labor economics literature on the effect of technological advancements on the labor market (Deming 2017; Deming and Kahn 2018; Hershbein and Kahn 2018) by focusing specifically on the audit industry. While understanding how technologies have affected the demand for skills in the overall economy is undoubtedly important, there is substantial heterogeneity in the role of technology across different industries within an economy, across different firms within an industry, and even across different functions within a firm. By focusing on a specific industry with rich institutional features, our study can provide unique insights that are of interest not only to researchers, but also to accounting professionals, regulators, and educators. 
Finally, the increasing use of emerging technologies in auditing has important implications for accounting educators. Data analytics has started to be integrated into accounting curricula, ${ }^{4}$ but there remains substantial room for growth. Informing accounting educators about the demand for data analytics skills has the potential to both spearhead this growth and shape how educators prepare the next generation of auditors by informing them about the skills now demanded in the profession.

The rest of the paper is organized as follows. Section 2 provides a brief review of the related literature and introduces our research questions. Section 3 describes our sample. Section 4 presents our main empirical results. Section 5 reports results of additional analyses. Section 6 concludes.

\section{Related Literature}

Our study is most related to two streams of literature: the accounting literature that examines the determinants of audit quality and the labor economics literature that studies the effect of technological changes on labor markets.

\subsection{Audit Quality}

Considerable research in accounting has been devoted to studying the determinants of audit quality. For instance, prior research suggests that audit firms have various incentives to produce high quality audits to manage reputational risks as well as to mitigate litigation risk (Weber et al. 2008; Skinner and Srinivasan 2012; Lobo and Zhao 2013). This research also examines auditor competencies and finds that industry specialization and Big $\mathrm{N}$ office sizes are positively associated with audit quality (Balsam et al. 2003; Reichelt and Wang 2010; Francis and Yu 2009; Choi et al. 2010). ${ }^{5}$

Despite a rich literature on the determinants of audit quality, there is relatively scant research on how auditor attributes affect audit quality. Recent studies find that audit partner characteristics are

\footnotetext{
${ }^{4}$ For instance, KPMG has partnered with nine business schools across the US to offer a "Master of Accounting with Data and Analytics Program" for their employees.

https://home.kpmg/us/en/home/media/press-releases/2017/08/kpmg-expands-award-winning-master-of-accountingwith-data-and-analytics-program.html

${ }^{5}$ See DeFond and Zhang (2014) and Donovan, Frankel, Lee, Martin and Seo (2014) for a more thorough review of the auditing literature.
} 
associated with audit quality (Aobdia et al. 2015; Chi et al. 2017; Gul et al. 2013; Knechel et al. 2015), but we are unaware of any studies that have examined the influence of staff auditors' characteristics. A recent survey by Defond and Zhang (2014) calls for more research to explore how different dimensions of auditor competencies, including the traits of individual auditors, affect audit quality. We add to this literature by examining the demand for specific auditor skills.

Our study is also related to a growing literature on audit productivity - the efficiency with which audit inputs (e.g., audit hours) are transformed into audit outputs (e.g., audit quality). Due to data limitations, prior studies tend to use proprietary data from non-US countries to study this relation (Blokdijk et al. 2006; Caramanis and Lennox 2008). However, with the availability of proprietary audit input data at the engagement level from the PCAOB, recent studies have begun to examine how engagement level inputs such as audit hours, auditor rank, and auditor experience affect audit quality (Aobdia, Siddiqui, and Vinelli 2018; Aobdia, Choudhary, and Newberger 2018; Gipper, Hail, and Leuz 2018). ${ }^{6}$ Our study complements this research by introducing auditor skills as another input that affects audit quality.

\subsection{Technological Advancements and Skill Requirements in Labor Markets}

A growing economics literature studies how technological changes (e.g., the computerization of the labor market in the US) affect the demand for labor skills (Auto, Levy, and Murnane 2003; Autor, Katz, and Kearney 2008; Acemoglu and Autor 2011; Goos, Manning, and Salomons 2014). Advances in computing power have expanded the set of tasks that machines can perform, from basic routine-manual tasks to more complicated tasks such as financial management and tax preparation (Levy and Murnane 2012; Brynjolfsson and McAfee, 2014; Remus and Levy 2017). However, certain skills, such as social and cognitive skills, are less likely to be replaced by technology. One's ability to read and react to others is based on tacit knowledge, and these abilities are likely complementary to

\footnotetext{
${ }^{6}$ For instance, Aobdia, Choudhary, and Newberger (2018) shows that higher audit hours and a more experienced audit team are associated with higher audit quality at the engagement level. This study also provides a nice summary of the literature on audit productivity.
} 
the advancement of technology (Autor, David, and Gordon 2015; Lu 2015). Technological advances may thus lead to a polarized labor market where technology brings substantial growth in the employment of high-skill occupations and low-skill manual service occupations at the expense of middle-skill occupations (Autor, Levy, and Murnane 2003; Autor, Katz, and Kearney 2006).

Our study complements this literature by studying the interactions between technology and labor skill demands for a specific industry, auditing. By focusing on a specific industry with rich institutional features, our study can provide unique insights that are of interest not only to researchers, but also to accounting professionals, regulators, and educators.

\subsection{Research Questions}

We empirically test three sets of research questions. First, audit firms are beginning to adopt and integrate new technologies such as process automation (e.g., self-service data extraction from financial or operational systems) and artificial intelligence into the audit process. As this occurs, certain functions, especially traditionally time-consuming manual tasks (e.g., contract review and asset verification), may be performed more efficiently by machines than employees. This may affect audit firms' demand for both auditors and non-auditor technology staff. Therefore, our first set of research questions is as follows:

RQ1a: During our sample period, has the demand for auditors decreased?

RQ1b: During our sample period, has the demand for non-audit IT staff increased?

Second, we argue that emerging technologies may affect not only the composition of audit firm staff, but also the skill sets that audit firms demand from auditors. With the prevalence of data analytics, artificial intelligence, and distributed ledger technologies, audit firms cannot afford to invest only in new technology without obtaining the necessary talent to leverage these technologies. Audit firms are likely employing data scientists, who can help auditors to capitalize on new technological tools, while simultaneously recruiting and training auditors to have the relevant skill sets to implement these new 
tools. The demand for auditors to acquire technological skills is evident in the increasingly data-driven curriculum in both undergraduate and masters accounting programs.

Meanwhile, as machines take on more routine-based manual audit tasks, other auditor skills may become more pertinent as auditors focus on tasks that require (i) subjective and qualitative judgment, and (ii) collaboration both with audit team members and with clients. This is likely to be reflected by a greater demand for cognitive and social skills. Finally, these increases in skill demands will either lead to audit firms demanding more skilled auditors ('upskilling') or substituting for skills that were previously demanded. Therefore, our second set of research questions is as follows: RQ2a: During our sample period, has audit firms' demand for technology skills increased? RQ2b: During our sample period, has audit firms' demand for cognitive and social skills increased? RQ2c: During our sample period, has audit firms' demand for total skills increased (upskilling)?

Third, the ultimate goal of investing in technology and talent is to remain competitive and improve audit quality. However, it is unclear how the various skills we study will map into audit quality. To the extent that a high-quality audit requires not only efficient use of data, but also sound judgement and collaborative teamwork, cognitive and social skills may complement technologyrelated skills in the audit process. Therefore, our third research question is as follows:

RQ3: Are technology, cognitive, or social skills associated with audit quality?

\section{Data}

We use a recently developed dataset from Burning Glass Technologies (BG) to capture audit firms' demand for certain job types and the associated skill requirements. BG is an employment analytics and labor market information firm. BG's algorithms continually scrape roughly 40,000 online job boards and company websites to aggregate and parse job postings. BG's proprietary algorithms remove duplicate postings and convert them into a systematic, machine-readable format. The end result is a dataset of nearly 100 million electronic job postings in the United States from January 2007 to 
December 2017, which we obtain through an agreement with BG. $^{7}$ The dataset contains detailed information corresponding to each unique job posting, including the date of the posting, the job title, the geographical location of the job, the skills required for the job, the name of the employer (for about $65 \%$ of postings), as well as education and experience requirements (for about $50 \%$ of the postings). The large sample size allows us to explore the potential heterogeneity in skill demands over time as well as across audit firms and across offices within the same firm.

An important question about the BG data is whether they accurately capture audit firms' demand for auditors or auditor skills, because a firm's job postings may not be representative of its actual employment. Hershbein and Kahn (2018) use the data to study how the Great Recession altered firms' demand for routine-based jobs, and they perform several validity checks by comparing the BG data to other data sources such as the Job Openings and Labor Turnover Survey (JOLTS) and the Current Population Survey, which list job vacancies at the industry or occupation level. Hershbein and Kahn (2018) find the BG data to provide a strong representation of white-collar occupations (e.g., computer, mathematical, management, healthcare practitioner, business occupations), whereas bluecollar occupations (e.g., transportation, food preparation and serving, production, construction) tend to be less well-represented. ${ }^{8}$ This appears reasonable given that white-collar job seekers likely use the internet to find a job at a higher rate than blue-collar job seekers. Given that auditor jobs are whitecollar positions, these patterns suggest that the BG data should be reasonably accurate in capturing demand for auditors.

To identify the audit firms and related job postings in BG, we manually match the audit firm names in Audit Analytics to the BG data. Given that the job postings provide location data we further restrict the sample to cities in which the corresponding auditor conducted at least one audit over our sample period. Our initial sample comprises 554,224 job postings, by 107 unique audit firms (876

\footnotetext{
${ }^{7}$ The BG data exclude the years 2008 and 2009.

${ }^{8}$ See their internet appendix for details: https://assets.aeaweb.org/assets/production/files/7383.pdf
} 
unique audit offices) over the period from 2007 to 2017. Table 1 Panel A reports the sample distribution over the sample period, separately for Big 4 and non-Big 4 audit firms. $84 \%$ of the job postings are made by Big 4 firms, and this figure is relatively stable over the sample period - the posts by Big 4 firms comprise over $80 \%$ of total posts in seven of the nine years.

To provide support that our sample is representative of the audit market, we compare the distribution of job postings across different cities in the BG data to the distribution across of audit fees across different cities in Audit Analytics. Specifically, Table 1 Panel B reports the top 20 cities based on job postings in our BG sample and the top 20 cities based on audit fees in the cross-section of Audit Analytics coverage during our sample period. Among the top 20 cities, 18 appear in both lists. Moreover, the top 20 cities both comprise roughly $73 \%$ of their respective populations.

\section{Empirical Tests}

\subsection{Audit Firms’ Labor Demands}

We categorize each job post into four job types: Audit, Tax, Advisory, and IT (Information Technology). ${ }^{9}$ In Table 1 Panel C, we report the job type distribution over our sample period. One takeaway is that the demand for audit jobs and tax jobs appear to be decreasing and the demand for advisory and IT jobs appear to be increasing over the period from 2007 to 2017. In 2007, audit job postings and tax job postings comprise about $22 \%$ and $30 \%$ of all the job postings by audit firms in our sample, respectively. By 2017, audit job postings and tax job postings comprise only about $7 \%$ and $10 \%$, respectively. In contrast, in 2007 , IT-related job postings are only $3 \%$ of the job postings, but $21 \%$ in 2017 . The relative demand for advisory jobs also increased from $14 \%$ in 2007 to $31 \%$ in 2017. For other job types, there is no clear trend during our sample period. The relatively stable share

\footnotetext{
${ }^{9} \mathrm{BG}$ provides the job title from the online job posting, but the job titles are quite unstandardized. For example, there are over 100,000 unique job titles in the dataset. We use a series of keywords to categorize each job title into the various functions. We then iteratively hand check a sample of the (most frequent) job titles and update the keywords accordingly. We are able to categorize over $70 \%$ of the job postings. Many of the remaining job posts pertain to other job functions (e.g., marketing, lawyers, support staff, etc.), though not all.
} 
of other job types helps assuage concerns that the trends we observe are driven by misclassifications in our job type categorization. Next, we more formally examine how the demand for these job functions has changed over our sample period.

Our first set of research questions suggests that audit firms' demand for labor will shift over our sample period. To formally test our first set of research questions, we estimate the following OLS regression model:

$$
\% \text { Job Type }=\beta_{0}+\beta_{1} * \text { Time Trend }+\Sigma \beta_{k} * \text { Control Variables }+\varepsilon \text {, }
$$

where \% Job Type is the proportion of the corresponding job type relative to all job postings by an audit firm or office in the corresponding calendar year. Since we are unable to identify the exact time at which audit firms began to adopt various emerging technologies, we examine how their demand for different types of positions shifted over the sample period. We capture this shift using the variable Time Trend, which is equal to corresponding calendar year, rescaled to be between zero and one. ${ }^{10} \mathrm{We}$ conduct these tests at the audit firm by year level and include audit firm fixed effects or at the audit office by year level and include audit office fixed effects. ${ }^{11}$ Controlling for audit firm or audit office fixed effects helps to rule out the possibility that labor demand composition varies with the firm or office's geographical location or some other unobservable firm or office effect. Standard errors are clustered by year. To mitigate the potential noise in our measure, we require a minimum of 30 job postings by each audit firm/office-year. This results in 237 audit firm-year observations for the audit firm level analysis and 1,954 audit office-year observations for the audit office level analysis.

Table 2 Panel A (B) reports the regression results of equation (1) at audit firm (office) level. Consistent with $\mathrm{H} 1 \mathrm{a}$ and $\mathrm{H} 1 \mathrm{~b}$, in both cases we observe a statistically significant increase in IT job demand and a decrease in audit job demand. At the audit firm level, the proportion of IT job postings increased by $3 \%$ whereas the proportion of audit job postings decreased by $6.7 \%$. The effects are even

\footnotetext{
${ }^{10}$ The sample period is 2007 to 2017 so this variable is equal to (year $\left.\mathrm{t}-2007\right)$ / (2017 - 2007).

${ }^{11}$ Throughout the paper we consider each audit firm by city combination a unique audit office.
} 
more pronounced at the audit office level. At the audit office level, the proportion of IT job postings increased $8.9 \%$ and the proportion of audit job postings decreased $7.7 \% .{ }^{12}$ Results also show that the relative demand for advisory jobs has increased 5\% (10\%) and the relative demand for tax job has decreased 5\% (9\%) in the audit firm (office) level analysis. These observations are consistent with the summary statistics reported in Table 1 Panel C. We also see no significant changes in the proportion of uncategorized jobs, suggesting our findings are driven by shifts between the job functions we have identified and not by shifts to and from unclassified jobs.

Next, we examine whether the shifts in job demands we have documented vary across Big 4 and non-Big 4 firms by interacting the time trend in equation (1) with an indicator variable for Big 4 status. The results are reported in Table $3 .{ }^{13}$ As in Table 2, Panel A reports the results from the firm level analysis and Panel B reports the results from the office level analysis. In both cases, we see the increase in demand for IT-related positions is driven almost entirely by the Big 4 firms. The main effect on the time trend is insignificant in the firm level analysis and it is weakly significant in the office level analysis, but has a magnitude less than $50 \%$ of the corresponding coefficient in Table 2 . Conversely, we see the reduction in audit job postings is less pronounced for the Big 4 firms. Whereas the reduction in audit job postings is $7 \%(12 \%)$ in the firm (office) level analysis for non-Big 4 firms, the corresponding reductions are only $4 \%(5 \%)$ for the Big 4 firms, though these decreases are still statistically significant.

\subsection{Audit Firms' Skill Demands}

As noted earlier, the BG dataset includes the skills that are demanded in each job posting, which allows us to empirically analyze the skill sets of auditors. Auditors' skill sets are one of the most important audit inputs (Defond and Zhang, 2014; Aobdia 2019). However, due to lack of data,

\footnotetext{
${ }^{12}$ Different estimates at the audit firm level and audit office level could be caused by the heterogeneity in labor demand across offices within the same audit firm.

${ }^{13}$ The main effect for the Big 4 indicator variable is absorbed by the audit firm or audit office fixed effects.
} 
empirical analysis on the skill sets of auditors has yet to be studied in the prior literature. In this section, we attempt to take a step towards filling that void.

BG cleans and codes the text of job ads into a taxonomy of thousands of unique but standardized skill requirements. Beginning with a set of predefined possible skills, BG uses machinelearning algorithms to search text in an ad for an indication that the skill is required. For example, for teamwork-related skills, BG searches for the keyword "teamwork" but also searches for similar variations such as "ability to work as a team." BG then categorizes its keywords into a series of skill demands. We thus use these skills to better understand what types of skills audit firms are demanding from auditors and whether there is heterogeneity in the skill demands across time, across audit firms, or even across audit offices within the same audit firm.

Of the 554,224 job postings examined in Tables 1 through 3, 58,355 correspond to audit jobs, and this subset of audit job postings contains over 2,000 uniquely identified skills. ${ }^{14}$ Figure 1 presents a word cloud of the top 200 skills that appear in our sample to provide some intuition behind the types of skills BG categorizes. ${ }^{15}$ Clearly, key words representing accounting knowledge such as "accounting," "financial reporting," and "financial statements" are the most prominent skills in the audit job postings. Besides financial skills, other prominent skills include "communication skills," “mentoring," "writing," "research," "leadership," "people management," "team work/collaboration," “oracle," "sap," “sas," "computer literacy," among others.

Because the skills demanded are not standardized across different audit firms, following existing literature on job task analysis (i.e., Deming and Kahn 2018; Hershbein and Kahn 2018), we develop a set of key words to categorize three sets of auditor skills that are likely to be most affected by technological changes in the audit industry: IT skills, cognitive skills, and social skills. In addition, we also consider financial skills given their relevance for auditors. IT skills include keywords such as

\footnotetext{
14 The whole BG database contains over 10,000 uniquely identified skills.

${ }^{15}$ In terms of the frequency skills appear in the sample, the frequency of the top 200 ranked skills comprises $91.8 \%$ of the total number of skills in the sample.
} 
“computer," "data," "spreadsheets," or are classified as software-related by BG. Cognitive skills include keywords such as "problem solving," "research," and "analytical." Social skills include keywords such as "communication," "teamwork," and "collaboration." Financial skills include keywords such as "accounting," "financial reporting," and "auditing”. In Panel A of Table 4 we report the keywords and phrases that fall into each category. We choose these keywords and phrases based on existing economic literature studying job tasks (Deming and Kahn, 2018; Deming and Noray, 2019) and by reading the skills within our audit job posting sample.

Table 4 Panel B reports descriptive statistics for the skill categories within the subset of audit job postings. For each skill category we report three measures to capture the degree of importance for the corresponding skill in the job post. First, the number of skills demanded in the corresponding skill type captures the intensity of skill requirement. For example, \#(Cognitive Skill) is the number of cognitive skills demanded in the job post. Second, the number of skills demanded in the corresponding skill type scaled by total skills demanded in the job post captures the relative weight of different skill requirements. For example, $\%($ Cognitive Skill) is the ratio of the number of cognitive skills demanded to the total number of skills demanded in a job posting. Third, we incorporate a series of indicator variables for the presence of a corresponding skill type to capture the extensive margin of the job skill requirement. For example, variable I(Cognitive Skill) equals one if a job posting requires at least one cognitive skill, zero otherwise. The variables are defined analogously for IT, social, and financial skills.

The audit job postings in our sample contain an average of 12 unique skills demanded per job post. As might be expected, a large portion of these skills are financial - the job posts contain an average of 5 financial skills per posting, $44 \%$ of the skills are financial, and $92 \%$ of the jobs contain at least one financial skill listed in the posting. However, there is more variation in the remaining skill types. For instance, $48 \%$ of the postings contain at least one cognitive skill whereas $61 \%$ contain a social skill, and 33\% contain an IT skill. On average, an audit job posting lists 0.8 cognitive skills, 1.5 
social skills and 1.2 IT skills. Collectively, the four skill categories we examine capture nearly $70 \%$ of the skills demanded in the audit job postings in our sample.

Table 4 Panel $\mathrm{C}$ reports the Pearson correlations among the different skill measures. As expected the total number of skills is positively correlated with each of the various skill measures. Moreover, focusing on the number of skills in the job post, all of the four defined skill types are positively correlated, but the correlations are quite low. For instance, the highest correlation is between the number of cognitive skills and the number of social skills at $33 \%$. In the next section we examine the determinants of these skill demands.

\subsection{Determinants of Auditor Skill Demands}

In this section, we examine the determinants of auditor skill demands. To explore the possible observable determinants of job postings for auditors, we begin by estimating the following OLS regression model:

$$
\begin{aligned}
\text { Skills }=\beta_{0} & +\beta_{1} * \text { Time Trend }+\beta_{2} * E d u+\beta_{3} * \operatorname{Exp}+\beta_{4} * I(E d u) \\
& +\beta_{5} * I(\text { Exp })+\beta_{6} * \text { Hierarchy }+\beta_{7} * \text { Big } 4+\varepsilon,
\end{aligned}
$$

where Skills are the different measures of skill requirements. Time Trend is equal to corresponding calendar year, rescaled to be between zero and one, as defined earlier. $E d u$ and $E x p$ are the number of years of education and experience required, respectively. Since some audit job postings do not have education and experience requirements, we also control for whether a job posting has education and experience or not. $I(E d u)$ and $I(E x p)$ take the value of 1 if a job posting lists and education or experience requirement, and otherwise takes the value 0 . We set $E d u$ and $\operatorname{Exp}$ to 0 when missing. Hierarchy is a variable coded to equal to 1 for interns, 2 for associates, and 3 for senior associates, 4 for managers, 5 for senior managers, 6 for directors, and 7 for partners. We categorize each job posting's hierarchy based on the job title in the posting. In our final sample for auditor job posting, $5.5 \%$ are interns, $24.9 \%$ are associates, $36.7 \%$ are senior associates, $24.1 \%$ are managers, $6.6 \%$ are senior managers, $2 \%$ are directors, and $0.2 \%$ are partners. Big4 is a dummy variable that takes the 
value of 1 if the job posting is issued by a Big4 audit firm. Standard errors are clustered by year and audit office. In the determinant analysis, we examine both the intensity of skill requirements (i.e., the number of skills required) and the relative weight of skill requirements (i.e., the percentage of skills in the corresponding skill type).

Table 5 reports the results of the determinants analysis. In column (1), the dependent variable is the total number of skills demanded in the job post. We find a significantly positive coefficient on the time trend, consistent with upskilling demonstrated in prior studies over this time period (Hershbein and Kahn 2018). In columns (2) through (6) we examine the number of skills within each skill category-cognitive, social, financial, IT, and other. Consistent with column (1), we again find a significantly positive coefficient on the time trend in each specification. Therefore, because all of the skill types are increasing over our sample period, to better understand how the overall skill sets of auditors are changing, we examine the relative proportion of each skill type in columns (7) through (11). We see that cognitive, social, and IT skills are making up a greater proportion of the skill requirements over the sample period. These increases in skill requirements are predominantly coming from the uncategorized skills while the financial skills remained relatively steady as a fraction of total skills over the sample period. This is consistent with the interpretation that with the advancement and application of information technology, IT skills, cognitive skills and social skills are becoming more important for audit professionals.

Several other findings are noteworthy. For instance, as may be expected, we find that more senior positions require more overall skills. This is predominantly driven by more social and financial skills whereas more senior job postings actually require fewer cognitive and IT skills. The Big 4 firms require more skills overall, though this tends to be driven by the uncategorized skills. Given reports that the Big 4 are investing more heavily into technology relative to the non-Big 4 audit firms, it may seem surprising that they do not require more IT skills from their auditors. However, our findings in Table 3 suggest the Big 4 firms are hiring more IT personnel in recent years. Therefore, the differential 
response may be related more to hiring IT-specific employees whereas the changes in skill demands for auditors is relatively steady across Big 4 and non-Big 4 firms.

\subsection{Heterogeneity in Auditor Skill Sets}

Next, we examine the degree to which a series of observable characteristics explains the variation in skill demands. Specifically, we regress the number of skills demanded in a job posting on a series of fixed effects and control variables and then gauge the degree to which each explains variation in the skill demands. We initially include audit firm, city, and year fixed effects, as well as controls for job seniority (e.g., associate, manager, etc.) and education and experience requirements.

$$
\begin{gathered}
\#(\text { Skill Requirement })=\beta_{0}+\beta_{1} * E d u+\beta_{2} * \operatorname{Exp}+\beta_{3} * I(E d u)+\beta_{4} * I(\operatorname{Exp}) \\
+\beta_{5} * \text { Hierarchy }+ \text { Audit Firm FE }+ \text { City FE }+ \text { Year FE }+\varepsilon,
\end{gathered}
$$

We estimate separate regressions for the total number of skills in the job posting as well as for the four skill categories (cognitive, social, IT, and financial). Table 6 Panel A reports the results. While the explanatory power varies by skill type, the audit firm is the dominant predictor of variation in the skill demands. Specifically, audit firms explain an average of $15 \%$ of the variation in skill demands whereas city explains $2 \%$ and year, education/experience, and seniority each explain $1 \%$ on average. There is considerable unexplained variation, $81 \%$ on average and ranging from $64 \%$ for social skills to $91 \%$ for IT skills. Next, we estimate similar models, but include audit office fixed effects, which is essentially an audit firm by city fixed effect. Results are reported in Table 6 Panel B. As expected, audit office dominates, explaining an average of $21 \%$ of the variation in skill demands whereas year, education/experience, and seniority each explain approximately $1 \%$ or less. The unexplained variation remains high at an average of $77 \%$ and ranging from $59 \%$ for social skills to $87 \%$ for IT skills.

Finally, we conduct this variance decomposition analysis at the audit office level by taking averages across all jobs in each audit office by calendar year. In these specifications we include auditor, city, and year fixed effects, along with controls for seniority, education, and experience requirements. Consistent with our expectation that taking the average of skill demands across job postings by office- 
year would reduce idiosyncratic factors that affect job posting skill demands, Table 6 Panel C shows significantly increased explanatory power. The audit firm fixed effects are the dominant factor, explaining an average of $38 \%$ of the variation in skill demands. Despite this, there still remains substantial unexplained variation at an average of $48 \%$ and ranging from $30 \%$ for social skills to $61 \%$ for IT skills.

In sum, this exercise provides preliminary evidence that audit offices have systematic differences in their recruiting strategies and possibly differences in skill utilization. It is worth noting that there is substantial remaining variation across audit job postings, which may reflect within audit office variation that we could not observe. In the next section, we exploit the discretion afforded to audit offices in the skills demanded of their auditors to better understand how auditor skills correlate with audit quality and audit fees.

\subsection{Auditor Skill Sets, Audit Quality, and Audit Pricing}

In this section, we examine whether the skill demands in an audit office's job postings is correlated with the audit outcomes for the corresponding office. To do so, we follow the audit quality framework provided by Defond and Zhang (2014). Specifically, on the supply side of audit quality, both auditor's incentives and competencies are main factors that affect audit quality. Our focus is on one important dimension of auditor competencies: auditors' skill sets as measured through the skill demands in job postings. Our approach builds on the existing audit literature that examines how audit partner characteristics contribute to audit quality (i.e., Chi et al., 2017; Lennox and Wu, 2018).

We also examine how auditor skills are correlated with audit pricing. Ex ante, it is unclear how auditor skills would be associated with audit pricing. On the one hand, more skilled auditors may demand higher wages, which may result in higher audit fees per audit hour. On the other hand, highly skilled auditors could increase work efficiency and thus reduce audit hours and the associated audit fees. Moreover, it is unclear how the different types of skills will correlate with both audit quality and audit fees. We therefore use the following empirical model to test our research questions: 
Our proxy for audit quality is client $10-\mathrm{K}$ restatements given that prior studies have suggested restatements are a direct measure of audit quality (Defond and Zhang, 2014; Christensen et al., 2016; Aobdia et al., 2019). We use a dichotomous variable (Restatement) that takes the value of 1 if the financial statement audited by audit office $j$ for client-firm $i$ in period $t$ is subsequently restated, and otherwise takes the value of 0 . Audit Fee $i j t$ is the $\log$ of audit fee by audit office $j$ for client-firm $i$ in the period $t$.

Due to the data limitations we are not able to identify engagement level auditor skill sets. Instead, we follow the existing literature and measure auditor characteristics at the audit office level (i.e., Beck, Gunn, and Hallman, 2019; Francis and Yu, 2009). Our office level skill measures capture the average skill requirement of all the audit job postings issued by the engagement audit office. For example, Office \#(Cognitive Skill) $)_{i j t}$, is measured as the arithmetic average of \#(Cognitive Skill) for all the audit job postings issued by audit office $j$ during the 12 months ending at the fiscal year end $t$ of client firm $i{ }^{16}$ To reduce the noise of our office level skill measures, we require a minimum of 10 audit job postings. We use the skill measures that capture the number of skills within the job posting (not the indicator or relative weights). We also separately examine total skills and the four skill categories for cognitive, social, IT, and financial skills. We estimate the model using either logistic or OLS regression, depending on the nature of the dependent variable, and cluster standard errors by each unique client firm.

We follow the existing literature to draw our set of control variables from several prior studies that investigate audit quality and audit pricing (e.g., Beck, Gun, and Hallman, 2019; Francis and Yu, 2014). To control for the effect of client characteristics, we include proxies for the following: client size (Client Size), leverage (Debt), performance (Loss), cash flows (Cash Flows), growth (Revenue

\footnotetext{
${ }^{16}$ We use a 12-month rolling window to calculate the average skill requirements. Specifically, we require at least 6 months' job postings observation.
} 
Growth), the variability of cash flows (Cash Flows SD) and revenue (Revenue SD). In the restatement model, we control for whether the financial statements were restated in the prior year (Restatement $t$-1), and in the audit fee model we control for the lagged audit fee Audit Fee $e_{t-1}$. In addition, we control for following audit office related variables: the length of the auditor-client relationship (Tenure), audit office size (Office Size), and audit-office industry market leadership (Industry Leader). We also include industry and year fixed effects.

Since there is a time lag between the time that a material misstatement occurs in a financial statement and the time that the misstatement is discovered and corrected, we end our sample period in 2016. ${ }^{17}$ Our final sample contains 7,482 audit engagements by 279 unique audit offices (28 unique audit firms). Table 7 Panel A provides summary statistics for our empirical analysis. On average, audit offices demand a total of 13 skills, 0.8 cognitive skill, 1.8 social skills, 5 financial skills and 1.2 IT skills.

Table 7 Panel B reports the regression results when the dependent variable is the dummy variable Restatement. From column (1) to column (5), we test how each skill measure is associated with the probability that a client firm's financial statement will be subsequently restated. Results in column (1) show that an audit office's average total number of skills is negatively associated with the probability of restatement. The coefficient of -0.057 is statistically significant at the $1 \%$ level. Results in columns (2) and (3) show that both auditor's cognitive skills and social skills have statistically significant negative associations with the probability of restatement. Our findings are consistent with our conjecture that both social skills and cognitive skills are important skills auditors need to effectively collect and communicate information and hence make critical audit judgments. Column (4) shows that financial skills are positively associated with the probability of restatement, though it is only marginally significant. The association between IT skills and restatement probability is negative but not statistically significant. Overall, these results suggest that offices with more skilled auditors

\footnotetext{
${ }^{17}$ Extending our sample period to 2017 does not qualitatively change our results.
} 
tend to produce higher quality audits, and this effect is driven by the cognitive and social skills, not the financial or IT skills.

Table 7 Panel $\mathrm{C}$ reports the regression results when the dependent variable is the log of audit fees charged to the client firm. The table is similarly organized as Panel B. The results show that all skill measures have a negative association with audit fees, but only total skills, cognitive skills and IT skills are statistically significant. Thus, our results are more consistent with the interpretation that auditors' skills could contribute to the efficiency of audit engagement and level of audit risk (i.e., lower probability of financial restatement) and consequently lower audit fees.

\section{Additional Tests}

\subsection{Controlling for City Fixed Effects}

One endogeneity concern about our findings on auditor's skill sets and audit quality/audit fees is that the association could be driven by some common factors shared by both the audit office and client firm. For example it is possible that in cities with better labor market conditions (i.e., more high quality or competitive labor markets), audit offices are more likely to require highly skilled auditors and client firms are also more likely to be equipped with high quality employees and thus have higher financial reporting quality. In untabulated analyses we include city fixed effect for all of the models in Table 7 and our inferences remain unchanged.

\subsection{Placebo test}

To provide extra evidence that our skill measures reflect audit office's demand for audit skills, we run a placebo test. We replace each audit office's job postings in a given year with a randomly chosen sample and re-run our audit quality and audit pricing test. Specifically, for each audit officeyear, we replace each job post within the audit office-year with another job post from outside the audit office-year that is chosen at random. We then estimate the models in Table 7 using the office skill measures based on the placebo job postings. We repeat the procedure 200 times and conduct t-test on 
the 200 estimated coefficients for the different skill measures. We find that all the estimated skill coefficients are not statistically different from zero.

\section{Conclusion}

The emergence of new technologies is redefining the labor market across all industries, including audit firms. In this study, we exploit a unique and nearly comprehensive dataset of online job postings by audit firms in the US from 2007 to 2017 to address three core research questions: 1) Has the demand for auditors and non-auditor information technology (IT) staff changed? 2) How the demand for auditor skill sets changed? 3) How are auditor's skill sets associated with audit quality and audit pricing?

First, we find that between 2007 and 2017, the demand for auditors has decreased, while the demand for IT-related personnel in audit firms has increased. Second, among the auditor positions in our sample, we find that audit firms are increasingly demanding more social, cognitive and IT-related skills. Third, auditor skills are positively (negatively) associated with audit quality (fees) and this effect is driven by cognitive and social skills (cognitive and IT skills).

Our study complements the existing literature that examines how auditor incentives and competencies affect audit quality (Defond and Zhang, 2014) by incorporating data on auditor skillsets. Our study also directly answers recent calls by the PCAOB for more research to understand how changes in technology impact the skillsets required for auditors and how technology affects the composition and structure of audit teams and the business model of audit firms (PCAOB, 2017). 


\section{References}

Acemoglu, D., and D. Autor. 2011. Skills, tasks and technologies: Implications for employment and earnings. In Handbook of labor economics, 4:1043-1171. Elsevier.

Aobdia, D. 2018. Do practitioner assessments agree with academic proxies for audit quality? Evidence from PCAOB and internal inspections. Journal of Accounting and Economics.

Aobdia, D., P. Choudhary, and N. Newberger. 2018. Which Audit Input Matters? An Analysis of the Determinants of Audit Quality, Profitability, and Audit Fees Using PCAOB Data. An Analysis of the Determinants of Audit Quality, Profitability, and Audit Fees Using PCAOB Data (December 12, 2018).

Aobdia, D., C.-J. Lin, and R. Petacchi. 2015. Capital market consequences of audit partner quality. The Accounting Review 90 (6): 2143-2176.

Aobdia, D., S. Siddiqui, and A. Vinelli. 2018a. Does engagement partner expertise matter? Evidence from the U.S. operations of the Big 4 audit firms. Northwestern University working paper.

Autor, D. H., D. Dorn, and G. H. Hanson. 2015. Untangling trade and technology: Evidence from local labour markets. The Economic Journal 125 (584): 621-646.

Autor, D. H., F. Levy, and R. J. Murnane. 2003. The skill content of recent technological change: An empirical exploration. The Quarterly journal of economics 118 (4): 1279-1333.

Autor, D., L. F. Katz, and M. Kearney. 2006. Measuring and interpreting trends in economic inequality. In AEA Papers and Proceedings, 96:189-194.

Balsam, S., J. Krishnan, and J. S. Yang. 2003. Auditor industry specialization and earnings quality. Auditing: A journal of practice \& Theory 22 (2): 71-97.

Blokdijk, H., F. Drieenhuizen, D. A. Simunic, and M. T. Stein. 2006. An analysis of cross-sectional differences in big and non-big public accounting firms' audit programs. Auditing: A Journal of Practice \& Theory 25 (1): 27-48.

Brynjolfsson, E., and A. McAfee. 2011. The big data boom is the innovation story of our time. The Atlantic 21.

2014. The second machine age: Work, progress, and prosperity in a time of brilliant technologies. WW Norton \& Company.

Caramanis, C., and C. Lennox. 2008. Audit effort and earnings management. Journal of accounting and economics 45 (1): 116-138.

Chi, W., L. A. Myers, T. C. Omer, and H. Xie. 2017. The effects of audit partner pre-client and clientspecific experience on audit quality and on perceptions of audit quality. Review of Accounting Studies 22 (1): 361-391.

Choi, J.-H., C. Kim, J.-B. Kim, and Y. Zang. 2010. Audit office size, audit quality, and audit pricing. Auditing: A Journal of practice \& theory 29 (1): 73-97.

Davenport, T. H., and J. Raphael. 2017. Creating a Cognitive Audit. CFO. com. http://ww2. cfo. com/auditing/2017/07/creating-cognitive-audit.

DeFond, M., and J. Zhang. 2014. A review of archival auditing research. Journal of Accounting and Economics 58 (2): 275-326. 
Deming, D. J. 2017. The growing importance of social skills in the labor market. The Quarterly Journal of Economics 132 (4): 1593-1640.

Deming, D., and L. B. Kahn. 2018. Skill requirements across firms and labor markets: Evidence from job postings for professionals. Journal of Labor Economics 36 (S1): S337-S369.

Donovan, J., R. Frankel, J. Lee, X. Martin, and H. Seo. 2014. Issues raised by studying DeFond and Zhang: What should audit researchers do? Journal of Accounting and Economics 58 (2): 327 338.

Francis, J. R., and M. D. Yu. 2009. Big 4 Office Size and Audit Quality. The Accounting Review 84 (5): 1521-1552.

Gipper, B., Leuz, C., and Maffett, M., 2019. Public Audit Oversight and Reporting Credibility: Evidence from the PCAOB Inspection Regime. Working Paper. Stanford University and University of Chicago.

Goos, M., A. Manning, and A. Salomons. 2014. Explaining job polarization: Routine-biased technological change and offshoring. American Economic Review 104 (8): 2509-2526.

Gul, F. A., D. Wu, and Z. Yang. 2013. Do individual auditors affect audit quality? Evidence from archival data. The Accounting Review 88 (6): 1993-2023.

Hershbein, B., and L. B. Kahn. 2018. Do recessions accelerate routine-biased technological change? Evidence from vacancy postings. American Economic Review 108 (7): 1737-1772.

Levy, F., and R. Murnane. 2012. The New Division of Labor: How Computers Are Creating the Next Job Market. The New Division of Labor: How Computers Are Creating the Next Job Market.

Levy, F., and R. J. Murnane. 2005. The new division of labor: How computers are creating the next job market. Princeton University Press.

Lobo, G. J., and Y. Zhao. 2013. Relation between audit effort and financial report misstatements: Evidence from quarterly and annual restatements. The Accounting Review 88 (4): 1385-1412.

Lowe, D. J., J. L. Bierstaker, D. J. Janvrin, and J. G. Jenkins. 2017. Information Technology in an Audit Context: Have the Big 4 Lost Their Advantage? Journal of information systems 32 (1): $87-$ 107.

Lu, Q. 2015. The end of polarization? Technological change and employment in the US labor market. Unpublished manuscript.

Norbert Tschakert, C. P. A., and C. P. A. Stephen Kozlowski. 2016. The next frontier in data analytics. Journal of Accountancy 222 (2): 58.

PCAOB 2017a. Technology and the Audit of Today and Tomorrow. Speeches \& Statement. Washington D.C.

PCAOB 2017b. Update on PCAOB Efforts to Enhance Audit Quality. Speeches \& Statement. Washington D.C.

PCAOB 2018. A Board Member's Perspective: PCAOB's 5-Year Strategic Plan, Transformation Initiatives, and Current Developments. Speeches and Statement. Philadelphia PA

Reichelt, K. J., and D. Wang. 2010. National and office-specific measures of auditor industry expertise and effects on audit quality. Journal of Accounting Research 48 (3): 647-686.

Remus, D., and F. Levy. 2017. Can Robots Be Lawyers: Computers, Lawyers, and the Practice of 
Law. Geo. J. Legal Ethics 30: 501.

Robert Knechel, W., A. Vanstraelen, and M. Zerni. 2015. Does the identity of engagement partners matter? An analysis of audit partner reporting decisions. Contemporary Accounting Research 32 (4): 1443-1478.

Skinner, D. J., and S. Srinivasan. 2012. Audit quality and auditor reputation: Evidence from Japan. The Accounting Review 87 (5): 1737-1765.

Weber, J., M. Willenborg, and J. Zhang. 2008. Does auditor reputation matter? The case of KPMG Germany and ComROAD AG. Journal of Accounting Research 46 (4): 941-972. 
Appendix A: Variable Definitions

\begin{tabular}{|c|c|}
\hline Variable & Definition \\
\hline \multicolumn{2}{|l|}{ Job Type Variables } \\
\hline$\%$ Audit & $\begin{array}{l}\text { the number of audit job postings divided by the total number of job } \\
\text { postings issued by an audit firm/office in a calendar year; }\end{array}$ \\
\hline$\%$ IT & $\begin{array}{l}\text { the number of IT job postings divided by the total number of job } \\
\text { postings issued by an audit firm/office in a calendar year; }\end{array}$ \\
\hline$\%$ Adv & $\begin{array}{l}\text { the number of advisory job postings divided by the total number of job } \\
\text { postings issued by an audit firm/office in a calendar year; }\end{array}$ \\
\hline$\% \operatorname{Tax}$ & $\begin{array}{l}\text { the number of tax job postings divided by the total number of job } \\
\text { postings issued by an audit firm/office in a calendar year; }\end{array}$ \\
\hline$\%$ Other & $\begin{array}{l}\text { the number of job postings other than audit, IT, advisory, and tax } \\
\text { divided by the total number of job postings; }\end{array}$ \\
\hline \multicolumn{2}{|c|}{ Skill Requirement Variables } \\
\hline \#(Total Skill) & the total number of skills demanded by a job posting; \\
\hline \#(Cognitive Skill) & the number of cognitive skills demanded by a job posting; \\
\hline \#(Social Skill) & the number of social skills demanded by a job posting; \\
\hline \#(IT Skill) & the number of IT skills demanded by a job posting; \\
\hline \#(Financial Skill) & the number of financial skills demanded by a job posting; \\
\hline \#(Other Skill) & $\begin{array}{l}\text { The number of skills other than cognitive, social, IT and financial } \\
\text { demanded by a job posting; }\end{array}$ \\
\hline I(Cognitive Skill) & 1 if a job posting requires at least 1 cognitive skill, otherwise 0 \\
\hline I(Social Skill) & 1 if a job posting requires at least 1 social skill, otherwise 0 \\
\hline I(IT Skill) & 1 if a job posting requires at least 1 IT skill, otherwise 0 \\
\hline I(Financial Skill) & 1 if a job posting requires at least 1 financial skill, otherwise 0 \\
\hline$\%($ Cognitive Skill $)$ & $\begin{array}{l}\text { number of cognitive skills demanded by a job posting divided the total } \\
\text { number of skills demanded; }\end{array}$ \\
\hline$\%$ ( Social Skill) & $\begin{array}{l}\text { number of social skills demanded by a job posting divided by the total } \\
\text { number of skills demanded; }\end{array}$ \\
\hline$\%($ IT Skill) & $\begin{array}{l}\text { number of IT skills demanded by a job posting divided by the total } \\
\text { number of skills demanded; }\end{array}$ \\
\hline$\%($ Financial Skill) & $\begin{array}{l}\text { number of financial skills demanded by a job posting divided by the } \\
\text { total number of skills demanded; }\end{array}$ \\
\hline$\%($ Other Skill) & $\begin{array}{l}\text { number of skills other than cognitive, social, IT and financial demanded } \\
\text { by a job posting divided by the total number of skills demanded; }\end{array}$ \\
\hline $\mathrm{I}(\mathrm{Edu})$ & $\begin{array}{l}\text { an indicator variable equal to } 1 \text { if a job posting lists an education } \\
\text { requirement, } 0 \text { otherwise; }\end{array}$ \\
\hline I(Exp) & $\begin{array}{l}\text { an indicator variable equal to } 1 \text { if a job posting lists an experience } \\
\text { requirement, } 0 \text { otherwise; }\end{array}$ \\
\hline Edu & $\begin{array}{l}\text { years of education demanded by a job posting conditional on the job } \\
\text { posting listing an education requirement; }\end{array}$ \\
\hline Exp & $\begin{array}{l}\text { years of experience demanded by a job posting conditional on the job } \\
\text { posting listing an experience requirement; }\end{array}$ \\
\hline Office \#(Total Skill) & $\begin{array}{l}\text { the average total number of skills demanded of all the audit job postings } \\
\text { issued by an audit office in a given period; }\end{array}$ \\
\hline Office \#(Cognitive Skill) & $\begin{array}{l}\text { the average number of cognitive skills demanded of all the audit job } \\
\text { postings issued by an audit office in a given period; }\end{array}$ \\
\hline
\end{tabular}




\section{Appendix A Continued}

\begin{tabular}{|c|c|}
\hline Office \#(Social Skill) & $\begin{array}{l}\text { the average number of social skills demanded of all the audit job } \\
\text { postings issued by an audit office in a given period; }\end{array}$ \\
\hline Office \# (IT Skill) & $\begin{array}{l}\text { the average number of IT skills demanded of all the audit job postings } \\
\text { issued by an audit office in a given period; }\end{array}$ \\
\hline Office \#(Financial Skill) & $\begin{array}{l}\text { the average number of financial skills demanded of all the audit job } \\
\text { postings issued by an audit office in a given period; }\end{array}$ \\
\hline \multicolumn{2}{|l|}{ Other Variables } \\
\hline Big4 & $\begin{array}{l}\text { an indicator variable equal to } 1 \text { if the engagement audit office is a Big } 4 \\
\text { audit firm office; } 0 \text { otherwise; }\end{array}$ \\
\hline Cash Flow & $\begin{array}{l}\text { total client-firm cash flows from operations (Compustat item OANCF) } \\
\text { scaled by total assets (Compustat item AT); }\end{array}$ \\
\hline Debt & $\begin{array}{l}\text { total client-firm debt (Compustat item DLTT) scaled by total assets } \\
\text { (Compustat item AT); }\end{array}$ \\
\hline Going Concern & $\begin{array}{l}\text { an indicator variable equal to } 1 \text { if the client-firm received a going } \\
\text { concern opinion in the current year; } 0 \text { otherwise (Audit Analytics item } \\
\text { Going_Concern); }\end{array}$ \\
\hline Industry Leader & $\begin{array}{l}\text { an indicator variable equal to } 1 \text { if the engagement audit office for the } \\
\text { current year collects more audit fees from clients in the same two-digits } \\
\text { SIC industry than any other office in the same city; } 0 \text { otherwise; }\end{array}$ \\
\hline Client Size & $\begin{array}{l}\text { The natural log of the client's total assets in millions of dollars } \\
\text { (Compustat item AT); }\end{array}$ \\
\hline Office Size & $\begin{array}{l}\text { the natural log of total audit fees generated during the current year by } \\
\text { the engagement audit office. An audit office is defined as all audits for } \\
\text { which the opinion is signed by a common audit firm (Audit Analytics } \\
\text { item Auditor_Fkey) and city name (Audit Analytics item } \\
\text { Auditor_City); }\end{array}$ \\
\hline Audit Fees & the natural log of audit fees paid by the client firm in the current year; \\
\hline Audit Fee ${ }_{t-1}$ & the natural $\log$ of audit fees paid by the client firm in year $\mathrm{t}-1$ \\
\hline Restatement & $\begin{array}{l}\text { an indicator variable equal to } 1 \text { if a firm-year's financial statements } \\
\text { were eventually restated for any reason, as reported by Audit } \\
\text { Analytics' Restatements database; } 0 \text { otherwise; }\end{array}$ \\
\hline Restatement $_{\mathrm{t}-1}$ & $\begin{array}{l}\text { an indicator variable equal to } 1 \text { if a firm-year's financial statements } \\
\text { from year t- } 1 \text { were eventually restated for any reason, as reported by } \\
\text { Audit Analytics' Restatements database; } 0 \text { otherwise. }\end{array}$ \\
\hline Loss & $\begin{array}{l}\text { an indicator variable equal to } 1 \text { if net income (Compustat item NI) is } \\
\text { negative; } 0 \text { otherwise; }\end{array}$ \\
\hline CFO SD & $\begin{array}{l}\text { the standard deviation of operating cash flows (Compustat item } \\
\text { OANCF) for the period } t-4 \text { through } \mathrm{t}-1 \text {; }\end{array}$ \\
\hline Revenue SD & $\begin{array}{l}\text { the standard deviation of client firm revenue (Compustat item REVT) } \\
\text { for the period } t-4 \text { through } \mathrm{t}-1 \text {; }\end{array}$ \\
\hline Revenue Growth & $\begin{array}{l}\text { total client-firm revenue in the current year (Compustat item REVT), } \\
\text { scaled by total client-firm revenue in year } t-1 \text {; }\end{array}$ \\
\hline Tenure & $\begin{array}{l}\text { the number of consecutive years that the same audit firm has issued } \\
\text { an opinion on the company's annual financial statements; }\end{array}$ \\
\hline
\end{tabular}




\section{Figures 1: Auditor Skill Sets}

The figure shows a word cloud for the top 200 ranked skills in terms of frequency in our auditor job postings sample. Word cloud is created using https://wordart.com. Wordart uses word frequency to determine the size of the words.

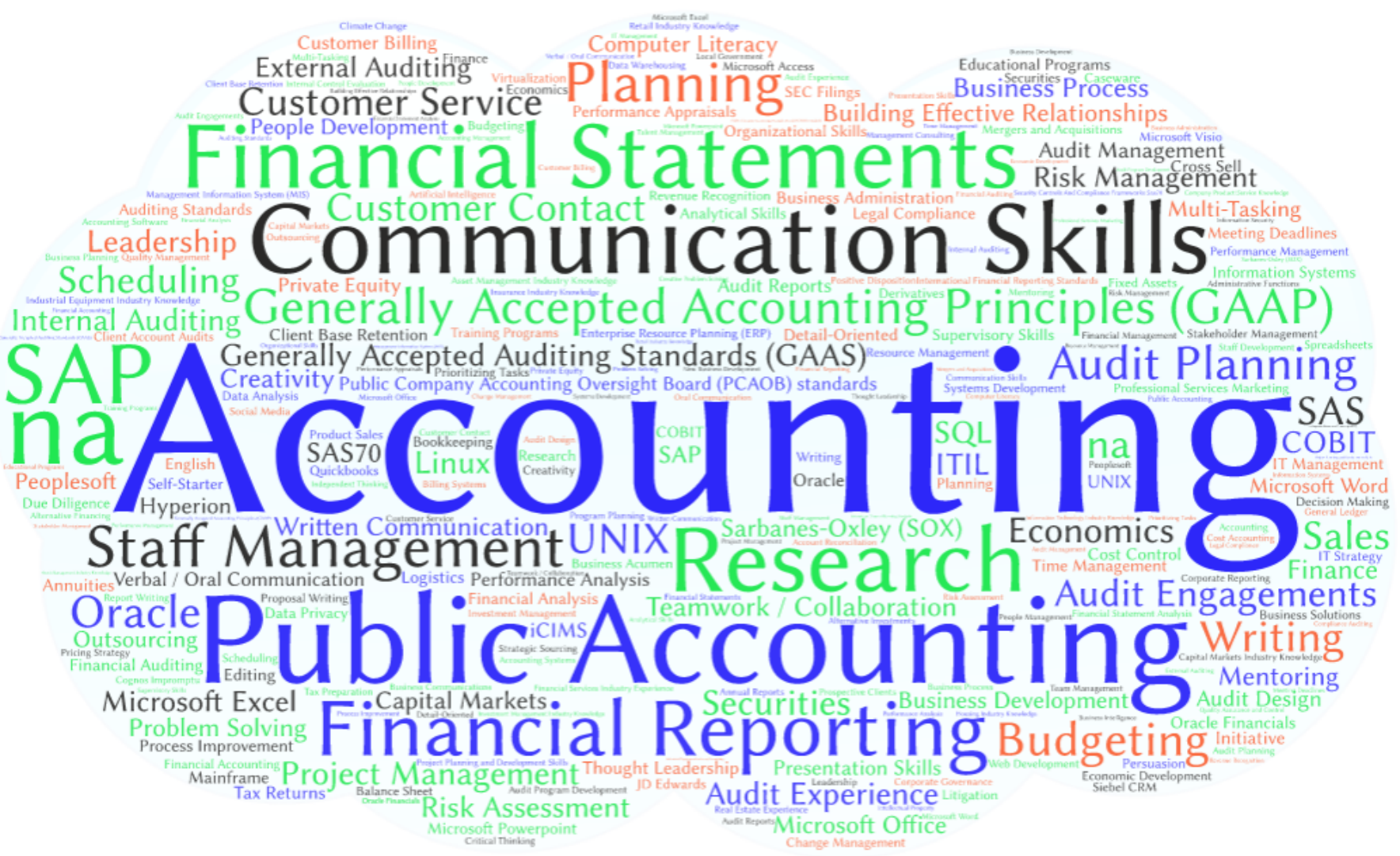




\section{Table 1. Sample Distribution}

Panel A presents the distribution of our final sample across years and Big4 versus Non-Big4 auditors. Our final sample is generated through manually matching the auditor name, state and city from Audit Analytics to the Burning Glass database. Panel B reports the top 20 cities in terms of number of job postings in our final job postings sample and the top 20 cities in terms of total audit fees in Audit Analytics. Panel C shows the distribution of different job types (i.e., Audit, Tax, Advisory, IT and Others) during our sample period.

Panel A: Sample Distribution over Sample Period

\begin{tabular}{|c|c|c|c|c|c|c|c|}
\hline \multirow[b]{2}{*}{ year } & \multirow[b]{2}{*}{ \# of obs } & \multicolumn{3}{|c|}{ Non-Big4 Auditors } & \multicolumn{3}{|c|}{ Big4 Auditors } \\
\hline & & \# of auditors & \# of obs & percent & \# of auditors & \# of obs & percent \\
\hline 2007 & 28509 & 31 & 9424 & $33.06 \%$ & 3 & 19085 & $66.94 \%$ \\
\hline 2010 & 21343 & 64 & 3936 & $18.44 \%$ & 3 & 17407 & $81.56 \%$ \\
\hline 2011 & 42076 & 71 & 8368 & $19.89 \%$ & 3 & 33708 & $80.11 \%$ \\
\hline 2012 & 37833 & 64 & 9600 & $25.37 \%$ & 4 & 28233 & $74.63 \%$ \\
\hline 2013 & 82035 & 77 & 12220 & $14.90 \%$ & 4 & 69815 & $85.10 \%$ \\
\hline 2014 & 103091 & 77 & 12449 & $12.08 \%$ & 4 & 90642 & $87.92 \%$ \\
\hline 2015 & 104584 & 76 & 12160 & $11.63 \%$ & 4 & 92424 & $88.37 \%$ \\
\hline 2016 & 69172 & 66 & 8962 & $12.96 \%$ & 4 & 60210 & $87.04 \%$ \\
\hline 2017 & 65581 & 71 & 9958 & $15.18 \%$ & 4 & 55623 & $84.82 \%$ \\
\hline Total & 554224 & 103 & 87,077 & $15.71 \%$ & 4 & 467147 & $84.29 \%$ \\
\hline
\end{tabular}


Table 1 Continued

Panel B: Top 20 Cities based on Job Postings and Audit Fees

\begin{tabular}{lll|lll}
\hline \hline \multicolumn{2}{c||}{ Top 20 Cities Based on Job Posting } & \multicolumn{3}{c}{ Top 20 Cities Based on Audit Fees } \\
\hline State & City & Percent & State & City & Percent \\
\hline New York & New York & $13.22 \%$ & New York & New York & $17.65 \%$ \\
Illinois & Chicago & $7.21 \%$ & Illinois & Chicago & $5.94 \%$ \\
Texas & Dallas & $5.12 \%$ & Massachusetts & Boston & $5.23 \%$ \\
California & Los Angeles & $4.69 \%$ & Texas & Houston & $4.67 \%$ \\
California & San Francisco & $4.69 \%$ & California & San Jose & $4.07 \%$ \\
Georgia & Atlanta & $4.62 \%$ & Pennsylvania & Philadelphia & $3.58 \%$ \\
Massachusetts & Boston & $4.01 \%$ & Texas & Dallas & $3.34 \%$ \\
Virginia & Mclean & $3.96 \%$ & California & Los Angeles & $3.25 \%$ \\
Pennsylvania & Philadelphia & $3.88 \%$ & Virginia & Mclean & $3.24 \%$ \\
Texas & Houston & $3.20 \%$ & Georgia & Atlanta & $3.06 \%$ \\
Minnesota & Minneapolis & $2.66 \%$ & California & San Francisco & $2.96 \%$ \\
North Carolina & Charlotte & $2.36 \%$ & Connecticut & Stamford & $2.18 \%$ \\
Michigan & Detroit & $1.97 \%$ & Michigan & Detroit & $2.15 \%$ \\
California & San Jose & $1.97 \%$ & North Carolina & Charlotte & $2.13 \%$ \\
Washington & Seattle & $1.95 \%$ & Minnesota & Minneapolis & $1.99 \%$ \\
Colorado & Denver & $1.81 \%$ & Colorado & Denver & $1.72 \%$ \\
D.C. & Washington & $1.70 \%$ & Washington & Seattle & $1.52 \%$ \\
Ohio & Cleveland & $1.49 \%$ & Missouri & Saint Louis & $1.46 \%$ \\
Connecticut & Stamford & $1.44 \%$ & Ohio & Cleveland & $1.45 \%$ \\
New Jersey & Parsippany & $1.43 \%$ & Connecticut & Hartford & $1.22 \%$ \\
Others & Others & $26.63 \%$ & Others & Others & $27.20 \%$ \\
\hline \hline
\end{tabular}


Table 1 Continued

Panel C: Sample Distribution over Different Job Types

\begin{tabular}{cccccccccccc}
\hline \hline Year & Total Obs & \multicolumn{2}{c}{ Audit Jobs } & \multicolumn{2}{c}{ Tax Jobs } & \multicolumn{2}{c}{ IT Jobs } & \multicolumn{2}{c}{ Advisory Jobs } \\
\hline 2007 & 28509 & 6261 & $21.96 \%$ & 8652 & $30.35 \%$ & 982 & $3.44 \%$ & 4090 & $14.35 \%$ & 8524 & $29.90 \%$ \\
2010 & 21343 & 3059 & $14.33 \%$ & 4965 & $23.26 \%$ & 1857 & $8.70 \%$ & 3396 & $15.91 \%$ & 8066 & $37.79 \%$ \\
2011 & 42076 & 7377 & $17.53 \%$ & 9924 & $23.59 \%$ & 3342 & $7.94 \%$ & 9415 & $22.38 \%$ & 12018 & $28.56 \%$ \\
2012 & 37833 & 5456 & $14.42 \%$ & 6258 & $16.54 \%$ & 4285 & $11.33 \%$ & 11321 & $29.92 \%$ & 10513 & $27.79 \%$ \\
2013 & 82035 & 6882 & $8.39 \%$ & 9288 & $11.32 \%$ & 14242 & $17.36 \%$ & 29853 & $36.39 \%$ & 21770 & $26.54 \%$ \\
2014 & 103091 & 9361 & $9.08 \%$ & 10911 & $10.58 \%$ & 19422 & $18.84 \%$ & 36184 & $35.10 \%$ & 27213 & $26.40 \%$ \\
2015 & 104584 & 9994 & $9.56 \%$ & 12627 & $12.07 \%$ & 18937 & $18.11 \%$ & 33696 & $32.22 \%$ & 29330 & $28.04 \%$ \\
2016 & 69172 & 5444 & $7.87 \%$ & 7884 & $11.40 \%$ & 13593 & $19.65 \%$ & 21405 & $30.94 \%$ & 20846 & $30.14 \%$ \\
2017 & 65581 & 4521 & $6.89 \%$ & 6322 & $9.64 \%$ & 13588 & $20.72 \%$ & 21992 & $33.53 \%$ & 19158 & $29.21 \%$ \\
Total & 554224 & 58355 & $10.53 \%$ & 76831 & $13.86 \%$ & 90248 & $16.28 \%$ & 171352 & $30.92 \%$ & 157438 & $28.41 \%$ \\
\hline \hline
\end{tabular}




\section{Table 2. Audit Firm Demand for Labor over Time}

The table reports the results of Equation (1), the regression of the proportion of different job types relative to all job postings by an audit firm or office in the corresponding year (\% Audit, \% IT, \% Adv, \% Tax, and \% Other) on Time Trend. Panel A reports the results of the audit firm level analysis. Panel B reports the regression results at the audit office level. All variables are defined in Appendix A. Standard errors are clustered by year and $t$-stats are reported in parentheses. *,**, and $* * *$ denote statistical significance at the $10 \%, 5 \%$, and $1 \%$ level, respectively.

Panel A: Firm Level Job Type Regression

\begin{tabular}{lccccc}
\hline \hline \multirow{2}{*}{ Time Trend } & $\%$ Audit & $\%$ IT & $\%$ Adv & $\%$ Tax & $\%$ Other \\
\cline { 2 - 6 } & $-0.067^{* * *}$ & $0.030^{* * *}$ & $0.051^{*}$ & $-0.053^{* * *}$ & 0.039 \\
Constant & $(-4.184)$ & $(4.023)$ & $(2.107)$ & $(-6.898)$ & $(1.508)$ \\
& $0.299^{* * *}$ & $0.029^{* * *}$ & $0.110^{* * *}$ & $0.272^{* * *}$ & $0.290^{* * *}$ \\
& $(26.049)$ & $(5.497)$ & $(6.566)$ & $(49.686)$ & $(14.883)$ \\
Auditor Fixed Effect & Yes & Yes & Yes & Yes & Yes \\
$\mathrm{N}$ & 237 & 237 & 237 & 237 & 237 \\
Adj R & 0.646 & 0.592 & 0.754 & 0.628 & 0.538 \\
\hline \hline
\end{tabular}

Panel B: Office Level Job Type Regression

\begin{tabular}{lccccc}
\hline \multirow{2}{*}{ Time Trend } & $\%$ Audit & $\%$ IT & $\%$ Adv & $\%$ Tax & $\%$ Other \\
\cline { 2 - 6 } & $-0.077^{* * *}$ & $0.089^{* * *}$ & $0.099^{* * *}$ & $-0.090^{* * * *}$ & -0.022 \\
& $(-5.643)$ & $(7.711)$ & $(3.787)$ & $(-4.217)$ & $(-0.933)$ \\
Constant & $0.234 * * *$ & $0.047^{* * *}$ & $0.158^{* * *}$ & $0.275^{* * *}$ & $0.286^{* * *}$ \\
& $(20.507)$ & $(6.480)$ & $(9.933)$ & $(19.181)$ & $(15.570)$ \\
Office Fixed Effect & Yes & Yes & Yes & Yes & Yes \\
$\mathrm{N}$ & 1,954 & 1,954 & 1,954 & 1,954 & 1,954 \\
Adj $\mathrm{R}^{2}$ & 0.625 & 0.650 & 0.632 & 0.617 & 0.583 \\
\hline \hline
\end{tabular}


Table 3. Big 4 vs. non-Big 4 Demand for Labor over Time

The table reports results of Equation (1), the regression of the proportion of different job types relative to all job postings by an accounting firm or office in the corresponding year (\%Audit, \% IT, \%Adv, \% Tax, and \%Other) on Time Trend interacted with the indicator variable Big4 (Trend*Big4). Panel A reports the results of the audit firm level analysis. Panel B reports the regression results at the audit office level. All variables are defined in Appendix A. Standard errors are clustered by year and $t$-stats are reported in parentheses. ${ }^{*},{ }^{*}$, and $* * *$ denote statistical significance at the $10 \%, 5 \%$, and $1 \%$ level, respectively.

Panel A: Firm Level Job Type Regression with Big 4 Interaction

\begin{tabular}{|c|c|c|c|c|c|}
\hline & \% Audit & \% IT & $\% \mathrm{Adv}$ & $\%$ Tax & \% Other \\
\hline Time Trend & $\begin{array}{c}-0.072 * * * \\
(-4.356)\end{array}$ & $\begin{array}{c}0.013 \\
(1.058)\end{array}$ & $\begin{array}{l}0.051 * \\
(1.985)\end{array}$ & $\begin{array}{c}-0.048 * * \\
(-3.120)\end{array}$ & $\begin{array}{l}0.057 * \\
(2.017)\end{array}$ \\
\hline Trend *Big4 & $\begin{array}{l}0.028 * \\
(2.192)\end{array}$ & $\begin{array}{c}0.090 * * * \\
(3.805)\end{array}$ & $\begin{array}{c}0.004 \\
(0.172)\end{array}$ & $\begin{array}{c}-0.028 \\
(-0.464)\end{array}$ & $\begin{array}{c}-0.094 * * \\
(-2.732)\end{array}$ \\
\hline Constant & $\begin{array}{c}0.300 * * * \\
(25.782)\end{array}$ & $\begin{array}{c}0.032 * * * \\
(4.920)\end{array}$ & $\begin{array}{c}0.110 * * * \\
(6.552)\end{array}$ & $\begin{array}{c}0.271 * * * \\
(42.208)\end{array}$ & $\begin{array}{c}0.287 * * * \\
(14.608)\end{array}$ \\
\hline $\begin{array}{l}\text { F test of Time Trend }+ \text { Trend } * \text { Big } 4=0 \\
\text { F stats } \\
\text { F test } p \text { value }\end{array}$ & $\begin{array}{l}5.563 \\
0.046\end{array}$ & $\begin{array}{l}72.71 \\
0.000\end{array}$ & $\begin{array}{l}3.518 \\
0.097\end{array}$ & $\begin{array}{l}2.608 \\
0.145\end{array}$ & $\begin{array}{l}1.185 \\
0.308\end{array}$ \\
\hline $\begin{array}{l}\text { Auditor Fixed Effect } \\
N \\
\text { Adj } R^{2}\end{array}$ & $\begin{array}{c}\text { Yes } \\
237 \\
0.644\end{array}$ & $\begin{array}{c}\text { Yes } \\
237 \\
0.617\end{array}$ & $\begin{array}{c}\text { Yes } \\
237 \\
0.753\end{array}$ & $\begin{array}{c}\text { Yes } \\
237 \\
0.627\end{array}$ & $\begin{array}{c}\text { Yes } \\
237 \\
0.541\end{array}$ \\
\hline
\end{tabular}

Panel B: Office Level Job Type Regression with Big 4 Interaction

\begin{tabular}{lccccc}
\hline \hline & \% Audit & $\%$ IT & \% Adv & \% Tax & \% Other \\
\cline { 2 - 6 } Time Trend & & & & - & \\
& $-0.123 * * *$ & $0.042^{*}$ & $0.171^{* *}$ & $0.099 * * *$ & 0.009 \\
Trend *Big4 & $(-5.254)$ & $(2.168)$ & $(3.007)$ & $(-4.028)$ & $(0.197)$ \\
& $0.071 * *$ & $0.072 * *$ & $-0.110^{*}$ & 0.015 & -0.047 \\
Constant & $(2.382)$ & $(2.449)$ & $(-1.990)$ & $(0.245)$ & $(-0.653)$ \\
& $0.235 * * *$ & $0.048 * * *$ & $0.157 * * *$ & $0.275 * * *$ & $0.286 * * *$ \\
F test of Time Trend + Trend * Big4 $=0$ & $(22.048)$ & $(7.512)$ & $(10.252)$ & $(19.702)$ & $(16.135)$ \\
F stats & & & & & \\
F test p value & 10.32 & 48.74 & 14.15 & 4.540 & 1.031 \\
& 0.012 & 0.000 & 0.005 & 0.066 & 0.340 \\
Office Fixed Effect & & & & & \\
$\mathrm{N}$ & Yes & Yes & Yes & Yes & Yes \\
Adj R & 1,954 & 1,954 & 1,954 & 1,954 & 1,954 \\
\hline \hline
\end{tabular}




\section{Table 4: Description of Job Skills}

Panel A shows the authors' categorization of open text fields in Burning Glass Technologies data. Panel B shows the summary of skill demands for audit job postings in our final job posting sample with 58,355 observations ranging from 2007 to 2017.

\section{Panel A: Categorization of Job Skills}

\begin{tabular}{ll}
\hline \hline \multicolumn{1}{c}{ Job Skills } & \multicolumn{1}{c}{ Keywords and Phrases } \\
\hline Cognitive & $\begin{array}{l}\text { research, problem solving, creativity, thought leadership, analytic, multi-tasking, decision making, thinking, } \\
\text { calculation, analysis, statistic }\end{array}$ \\
Social & $\begin{array}{l}\text { communication, teamwork, collaboration, leadership, presentation, relationships, mentoring, people development, } \\
\text { team development, team building, public speaking, persuasion, listening, writ }\end{array}$ \\
& $\begin{array}{l}\text { computer, spreadsheets, data, microsoft, oracle, sap, sql, peoplesoft, java, hyperion, sad, unix, calypso, common } \\
\text { sttware (e.g., microsoft excel, powerpoint) }\end{array}$ \\
Financial & $\begin{array}{l}\text { accounting, budgeting, economics, finance, business, tax, cost, audit, sox, capital markets, fas109, sas70, fin48, } \\
\text { revenue recognition, balance sheet, sec filings, corporate reporting, annual reports, accruals }\end{array}$ \\
\hline \hline
\end{tabular}


Table 4 Continued:

Panel B: Summary Statistics of Audit Job Skill Demands

\begin{tabular}{llllll}
\hline \hline & \# Obs. & Mean & Sd & Min & Max \\
\cline { 2 - 5 } \#(Total Skill) & 58355 & 12.17 & 7.59 & 1 & 75 \\
\#(Cognitive Skill) & 58355 & 0.79 & 1.06 & 0 & 12 \\
\#(Social Skill) & 58355 & 1.46 & 1.69 & 0 & 12 \\
\#(Financial Skill) & 58355 & 5.03 & 3.38 & 0 & 24 \\
\#(IT Skill) & 58355 & 1.17 & 2.32 & 0 & 32 \\
\#(Other Skill) & 58355 & 3.97 & 3.39 & 0 & 56 \\
I(Cognitive Skill) & 58355 & 0.48 & 0.50 & 0 & 1 \\
I(Social Skill) & 58355 & 0.61 & 0.49 & 0 & 1 \\
I(Financial Skill) & 58355 & 0.92 & 0.27 & 0 & 1 \\
I(IT Skill) & 58355 & 0.33 & 0.47 & 0 & 1 \\
I(Other Skill) & 58355 & 0.90 & 0.30 & 0 & 1 \\
\%(Cognitive Skill) & 58355 & 0.06 & 0.08 & 0 & 1 \\
\%(Social Skill) & 58355 & 0.11 & 0.13 & 0 & 1 \\
\%(Financial Skill) & 58355 & 0.44 & 0.27 & 0 & 1 \\
\%(IT Skill) & 58355 & 0.07 & 0.12 & 0 & 1 \\
\%(Other Skill) & 58355 & 0.34 & 0.23 & 0 & 1 \\
Edu 18 & 58355 & 16.03 & 0.49 & 2.21 & 1 \\
Exp & 58355 & 3.77 & 2.31 & \\
\hline \hline
\end{tabular}

${ }^{18}$ For our sample, $20 \%(37 \%)$ of the audit job postings do not include an education requirement (experience requirement). 
Table 4 Continued

Panel C: Correlations between Skill Demands

\begin{tabular}{|c|c|c|c|c|c|c|c|c|c|c|c|c|c|c|c|c|}
\hline & $\begin{array}{l}\#(\text { Tot } \\
\text { Skill) }\end{array}$ & $\begin{array}{l}\#(\mathrm{Cog} \\
\text { Skill })\end{array}$ & $\begin{array}{l}\#(\text { Soc } \\
\text { Skill) }\end{array}$ & $\begin{array}{l}\#(\text { Fin } \\
\text { Skill })\end{array}$ & $\begin{array}{l}\#(\text { IT } \\
\text { Skill })\end{array}$ & $\begin{array}{l}\#(\text { Oth } \\
\text { Skill) }\end{array}$ & $\begin{array}{l}\text { I(Cog } \\
\text { Skill) }\end{array}$ & $\begin{array}{l}\text { I(Soc } \\
\text { Skill) }\end{array}$ & $\begin{array}{l}\text { I(Fin } \\
\text { Skill) }\end{array}$ & $\begin{array}{l}\text { I(IT } \\
\text { Skill) }\end{array}$ & $\begin{array}{l}\text { I(Oth } \\
\text { Skill) }\end{array}$ & $\begin{array}{l}\%(\mathrm{Cog} \\
\text { Skill })\end{array}$ & $\begin{array}{l}\% \text { (Soc } \\
\text { Skill) }\end{array}$ & $\begin{array}{l}\%(\text { Fin } \\
\text { Skill) }\end{array}$ & $\begin{array}{l}\%(\text { IT } \\
\text { Skill) }\end{array}$ & $\begin{array}{l}\% \text { (Oth } \\
\text { Skill) }\end{array}$ \\
\hline \#(Total Skill) & 1.00 & & & & & & & & & & & & & & & \\
\hline \#(Cognitive Skill) & 0.47 & 1.00 & & & & & & & & & & & & & & \\
\hline \#(Social Skill) & 0.46 & 0.33 & 1.00 & & & & & & & & & & & & & \\
\hline \#(Financial Skill) & 0.66 & 0.24 & 0.03 & 1.00 & & & & & & & & & & & & \\
\hline \#(IT Skill) & 0.64 & 0.15 & 0.13 & 0.16 & 1.00 & & & & & & & & & & & \\
\hline \#(Other Skill) & 0.85 & 0.32 & 0.34 & 0.34 & 0.55 & 1.00 & & & & & & & & & & \\
\hline I(Cognitive Skill) & 0.40 & 0.78 & 0.38 & 0.21 & 0.06 & 0.26 & 1.00 & & & & & & & & & \\
\hline I(Social Skill) & 0.46 & 0.40 & 0.70 & 0.14 & 0.18 & 0.34 & 0.43 & 1.00 & & & & & & & & \\
\hline I(Financial Skill) & 0.38 & 0.17 & 0.20 & 0.44 & 0.10 & 0.20 & 0.21 & 0.27 & 1.00 & & & & & & & \\
\hline I(IT Skill) & 0.55 & 0.30 & 0.21 & 0.16 & 0.72 & 0.47 & 0.19 & 0.29 & 0.13 & 1.00 & & & & & & \\
\hline I(Other Skill) & 0.32 & 0.17 & 0.19 & 0.13 & 0.12 & 0.39 & 0.17 & 0.26 & -0.05 & 0.12 & 1.00 & & & & & \\
\hline$\%($ Cognitive Skill) & 0.13 & 0.78 & 0.16 & 0.00 & -0.03 & 0.04 & 0.74 & 0.26 & 0.11 & 0.09 & 0.07 & 1.00 & & & & \\
\hline$\%($ Financial Skill) & -0.16 & -0.20 & -0.40 & 0.46 & -0.30 & -0.38 & -0.18 & -0.35 & 0.49 & -0.31 & -0.48 & -0.17 & -0.39 & 1.00 & & \\
\hline$\%($ IT Skill) & 0.38 & 0.07 & 0.07 & -0.01 & 0.83 & 0.31 & 0.00 & 0.14 & 0.03 & 0.77 & 0.02 & -0.03 & -0.03 & -0.32 & 1.00 & \\
\hline$\%$ (Other Skill) & -0.09 & -0.11 & -0.08 & -0.39 & -0.01 & 0.27 & -0.15 & -0.12 & -0.68 & -0.05 & 0.49 & -0.17 & -0.14 & -0.71 & -0.09 & 1.00 \\
\hline
\end{tabular}

Note: All correlations are significant at the 0.01 level. 
Table 5: Determinants of Audit Job Posting Skill Requirements

The table reports results of Equation (2), the regression of different skill demands (e.g., \#(Total Skill), \#(Cognitive Skill), \#(Social Skill)) on different job posting characteristics. All variables are defined in Appendix A. Standard errors are clustered by audit office and year, and $t$-stats are reported in parentheses. $* * *$, and $* * *$ denote statistical significance at the $10 \%, 5 \%$, and $1 \%$ level, respectively.

\begin{tabular}{|c|c|c|c|c|c|c|c|c|c|c|c|}
\hline & $\begin{array}{c}\text { \#(Total } \\
\text { Skill) }\end{array}$ & $\begin{array}{c}\# \text { (Cognitive } \\
\text { Skill) }\end{array}$ & $\begin{array}{c}\# \text { (Social } \\
\text { Skill) }\end{array}$ & $\begin{array}{c}\text { \#(Financial } \\
\text { Skill) }\end{array}$ & \#(IT Skill) & $\begin{array}{l}\text { \#(Other } \\
\text { Skill) }\end{array}$ & $\begin{array}{l}\% \text { (Cognitive } \\
\text { Skill) }\end{array}$ & $\begin{array}{l}\text { \%(Social } \\
\text { Skill) }\end{array}$ & $\begin{array}{c}\%(\text { Financial } \\
\text { Skill) }\end{array}$ & $\%$ (IT Skill) & $\begin{array}{c}\% \text { (Other } \\
\text { Skill) }\end{array}$ \\
\hline \multirow[t]{2}{*}{ Trend } & $3.340 * * *$ & $0.580 * *$ & $0.530 * * *$ & $0.854 * *$ & $0.661 * * *$ & $0.785^{* * *}$ & $0.035 * * *$ & $0.038 * * *$ & 0.002 & $0.029 * *$ & $-0.100 * *$ \\
\hline & $(-7.435)$ & (3.096) & $(6.701)$ & $(2.769)$ & $(4.251)$ & (4.710) & (3.391) & $(6.731)$ & $(0.037)$ & $(2.711)$ & $(-2.997)$ \\
\hline \multirow[t]{2}{*}{ Edu } & -0.099 & 0.007 & $0.254 * *$ & $0.180 *$ & $-0.225^{* * *}$ & $-0.336 * * *$ & 0.001 & $0.021 * * *$ & 0.008 & $-0.010 * * *$ & $-0.019 * * *$ \\
\hline & $(-0.455)$ & $(0.197)$ & $(2.461)$ & (1.911) & $(-4.406)$ & $(-3.928)$ & $(0.505)$ & (3.634) & (1.097) & $(-3.441)$ & $(-4.758)$ \\
\hline \multirow[t]{2}{*}{ Exp } & 0.244 & 0.035 & $0.099 * * *$ & -0.040 & 0.045 & 0.104 & 0.003 & $0.006 * * *$ & -0.007 & $0.003^{*}$ & $-0.005^{*}$ \\
\hline & (1.518) & (1.146) & (3.939) & $(-0.680)$ & (1.119) & $(1.486)$ & (1.857) & $(4.042)$ & $(-1.350)$ & (1.879) & $(-2.292)$ \\
\hline \multirow[t]{2}{*}{$\mathrm{I}(\mathrm{Edu})$} & 6.244 & 0.151 & $-3.638 *$ & 0.013 & $3.695 * * *$ & $6.369 * * *$ & 0.003 & $-0.318 * *$ & 0.035 & $0.159 * * *$ & 0.121 \\
\hline & (1.837) & $(0.250)$ & $(-2.166)$ & $(0.008)$ & $(4.594)$ & $(4.704)$ & $(0.077)$ & $(-3.335)$ & $(0.287)$ & (3.364) & $(1.800)$ \\
\hline \multirow[t]{2}{*}{$\mathrm{I}(\operatorname{Exp})$} & $2.864 * *$ & 0.026 & 0.322 & $1.014 *$ & $0.651 * *$ & $0.997 * *$ & -0.013 & 0.008 & -0.010 & $0.026^{* *}$ & -0.003 \\
\hline & $(2.541)$ & $(0.154)$ & $(1.440)$ & (1.997) & $(2.806)$ & $(2.307)$ & $(-1.480)$ & $(0.447)$ & $(-0.272)$ & $(2.731)$ & $(-0.154)$ \\
\hline \multirow[t]{2}{*}{ Hierarchy } & $0.515 * *$ & $-0.067 * *$ & $0.056^{* *}$ & $0.349 * * *$ & $-0.111 * *$ & $0.308 * * *$ & $-0.011 * * *$ & $-0.005^{*}$ & -0.003 & $-0.012 * * *$ & $0.031 * * *$ \\
\hline & (3.334) & $(-3.185)$ & $(2.566)$ & $(3.661)$ & $(-2.617)$ & $(4.631)$ & $(-4.589)$ & $(-2.198)$ & $(-0.390)$ & $(-5.000)$ & $(8.850)$ \\
\hline \multirow[t]{2}{*}{ Big4 } & $1.176^{*}$ & -0.085 & 0.020 & 0.268 & -0.010 & $0.802 * *$ & 0.001 & -0.007 & $-0.043 * *$ & -0.013 & $0.054 * * *$ \\
\hline & (2.036) & $(-1.088)$ & $(0.147)$ & (1.611) & $(-0.072)$ & $(3.084)$ & $(0.135)$ & $(-0.730)$ & $(-2.367)$ & $(-1.789)$ & $(5.368)$ \\
\hline \multirow[t]{2}{*}{ Constant } & $1.774 * *$ & $0.388 * *$ & 0.172 & 0.434 & $0.544 * *$ & 0.399 & $0.057 * * *$ & $0.075 * * *$ & $0.374 * * *$ & $0.078 * * *$ & $0.432 * * *$ \\
\hline & $(2.711)$ & $(2.689)$ & (1.375) & (1.174) & $(2.391)$ & (1.283) & $(5.872)$ & $(5.516)$ & $(8.327)$ & $(6.203)$ & $(8.322)$ \\
\hline $\mathrm{N}$ & 58,355 & 58,355 & 58,355 & 58,355 & 58,355 & 58,355 & 58,355 & 58,355 & 58,355 & 58,355 & 0.171 \\
\hline $\operatorname{Adj} R^{2}$ & 0.220 & 0.0544 & 0.103 & 0.200 & 0.0403 & 0.123 & 0.0474 & 0.0377 & 0.0548 & 0.0313 & 0.171 \\
\hline
\end{tabular}




\section{Table 6: Variances in Skill Requirements}

Panel A and B report the explanatory power of different factors affecting the variation of audit job posting skill requirements (\#(Social Skill), \#(Cognitive Skill), \#(Financial Skill), \#(IT Skill), and $\#($ Total Skill)). We regress the total number of skills demanded, the number of specific skills (i.e., Cognitive, Social, Financial, and IT) demanded by a job posting on audit firm/office fixed effects, and additional controls (city fixed effect, year fixed effect, education and experience requirements, and job position's hierarchy). Panel $\mathrm{C}$ reports results for similar analyses conducted at the audit office level. All skill requirements and job posting characteristics are aggregated at the audit office level. For example, Office \#(Social Skill) is the average number of total skill requirements for all the audit job postings issued by an audit office by calendar year.

Panel A: Job Posting Skill Requirement

\begin{tabular}{lccc}
\hline \hline Skill Type & Audit Firm Fixed Effect & Other Controls & Residual \\
\hline \#(Social Skill) & 0.33 & 0.03 & 0.64 \\
$\#$ (Cognitive Skill) & 0.13 & 0.05 & 0.81 \\
$\#($ Financial Skill) & 0.13 & 0.04 & 0.83 \\
$\#($ IT Skill) & 0.04 & 0.05 & 0.91 \\
$\#($ Total Skill) & 0.09 & 0.05 & 0.86 \\
\hline \hline
\end{tabular}

Panel B: Job Posting Skill Requirement

\begin{tabular}{lccc}
\hline \hline Skill Type & Audit Office Fixed Effect & Other Controls & Residual \\
\hline \#(Social Skill) & 0.39 & 0.01 & 0.59 \\
\#(Cognitive Skill) & 0.21 & 0.02 & 0.77 \\
\#(Financial Skill) & 0.19 & 0.02 & 0.80 \\
$\#($ IT Skill) & 0.11 & 0.02 & 0.87 \\
$\#$ (Total Skill) & 0.17 & 0.02 & 0.81 \\
\hline \hline
\end{tabular}

Panel C: Office Skill Requirement

\begin{tabular}{lccc}
\hline \hline Skill Type & Audit Firm Fixed Effect & Other Controls & Residual \\
\hline Office \#(Social Skill) & 0.63 & 0.07 & 0.30 \\
Office \#(Cognitive Skill) & 0.41 & 0.12 & 0.47 \\
Office \#(Financial Skill) & 0.35 & 0.15 & 0.50 \\
Office \#(IT Skill) & 0.22 & 0.17 & 0.61 \\
Office \#(Total Skill) & 0.22 & 0.17 & 0.61 \\
\hline \hline
\end{tabular}




\section{Table 7: Auditor Skill Sets, Audit Quality and Audit Pricing}

Table 7 reports results of Equation (4), the regression of audit quality (audit fees) on auditor skill sets. Panel A shows the descriptive statistics of the variables used in this sample. Panel B reports results of multivariate regressions of audit quality (restatement probability) on the engagement audit office's skill measures (Office \#(Total Skill), Office \#(Cognitive Skill), Office \#(Social Skill), Office \#(Financial Skill) and Office \#(IT skill) ). Panel B reports results of multivariate regression of the log of audit fees on the engagement audit office's skill measures. All variables are defined in Appendix A. Standard errors are clustered by client firm and $t$-stats are reported in parentheses. $* * *$, and $* * *$ denote statistical significance at the $10 \%, 5 \%$, and $1 \%$ level, respectively.

\section{Panel A: Descriptive Statistics}

\begin{tabular}{|c|c|c|c|c|c|c|}
\hline & Count & Min & Mean & Median & Max & $\mathrm{SD}$ \\
\hline Restatement & 7482 & 0.000 & 0.106 & 0.000 & 1.000 & 0.307 \\
\hline Restatement $_{\mathrm{t}-1}$ & 7482 & 0.000 & 0.111 & 0.000 & 1.000 & 0.315 \\
\hline Audfee & 7482 & 11.876 & 14.338 & 14.286 & 17.122 & 1.049 \\
\hline Audfee $_{t-1}$ & 7482 & 11.678 & 14.274 & 14.222 & 17.093 & 1.079 \\
\hline $\begin{array}{l}\text { Office \#(Total Skill) } \\
\text { Office \#(Cognitive }\end{array}$ & 7482 & 3.333 & 13.062 & 13.405 & 22.339 & 3.726 \\
\hline Skill) & 7482 & 0.088 & 0.774 & 0.673 & 2.240 & 0.484 \\
\hline $\begin{array}{l}\text { Office \#(Social Skill) } \\
\text { Office \#(Financial }\end{array}$ & 7482 & 0.000 & 1.842 & 1.326 & 5.059 & 1.474 \\
\hline Skill) & 7482 & 0.679 & 4.995 & 5.065 & 9.775 & 2.028 \\
\hline Office \#(IT Skill) & 7482 & 0.000 & 1.166 & 0.883 & 4.200 & 1.070 \\
\hline Going Concern & 7482 & 0.000 & 0.023 & 0.000 & 1.000 & 0.149 \\
\hline $\mathrm{CFO}$ & 7482 & -0.755 & 0.055 & 0.082 & 0.324 & 0.159 \\
\hline Debt & 7482 & 0.000 & 0.228 & 0.192 & 1.066 & 0.225 \\
\hline Client Size & 7482 & 2.548 & 7.136 & 7.177 & 11.665 & 1.926 \\
\hline Loss & 7482 & 0.000 & 0.296 & 0.000 & 1.000 & 0.457 \\
\hline Revenue Growth & 7482 & -0.612 & 0.112 & 0.060 & 2.235 & 0.345 \\
\hline Revenue SD & 7482 & 0.007 & 0.146 & 0.094 & 0.895 & 0.155 \\
\hline CFO SD & 7482 & 0.005 & 0.063 & 0.035 & 0.566 & 0.088 \\
\hline Industry Leader & 7482 & 0.000 & 0.596 & 1.000 & 1.000 & 0.491 \\
\hline Office Size & 7482 & 13.865 & 17.861 & 18.105 & 20.189 & 1.213 \\
\hline Tenure & 7482 & 0.000 & 8.028 & 8.000 & 16.000 & 4.481 \\
\hline
\end{tabular}




\begin{tabular}{|c|c|c|c|c|c|}
\hline & (1) & (2) & (3) & (4) & (5) \\
\hline \#(Total Skill) & $\begin{array}{c}-0.057 * * * \\
(-3.909)\end{array}$ & & & & \\
\hline \#(Cognitive Skill) & & $\begin{array}{c}-0.376^{* * *} * \\
(-3.211)\end{array}$ & & & \\
\hline \#(Social Skill) & & & $\begin{array}{c}-0.184 * * * \\
(-5.126)\end{array}$ & & \\
\hline \#(Financial Skill) & & & & $\begin{array}{l}0.039 * \\
(1.677)\end{array}$ & \\
\hline \#(IT Skill) & & & & & $\begin{array}{c}-0.052 \\
(-1.116)\end{array}$ \\
\hline Office Size & $\begin{array}{c}-0.047 \\
(-0.973)\end{array}$ & $\begin{array}{c}-0.044 \\
(-0.927)\end{array}$ & $\begin{array}{c}-0.032 \\
(-0.679)\end{array}$ & $\begin{array}{c}-0.048 \\
(-1.000)\end{array}$ & $\begin{array}{c}-0.056 \\
(-1.148)\end{array}$ \\
\hline Big4 & $\begin{array}{c}0.113 \\
(0.465)\end{array}$ & $\begin{array}{c}0.078 \\
(0.318)\end{array}$ & $\begin{array}{c}0.134 \\
(0.567)\end{array}$ & $\begin{array}{c}0.258 \\
(1.088)\end{array}$ & $\begin{array}{c}0.200 \\
(0.841)\end{array}$ \\
\hline Industry Leader & $\begin{array}{c}0.062 \\
(0.626)\end{array}$ & $\begin{array}{c}0.078 \\
(0.795)\end{array}$ & $\begin{array}{c}0.070 \\
(0.706)\end{array}$ & $\begin{array}{c}0.094 \\
(0.952)\end{array}$ & $\begin{array}{c}0.084 \\
(0.848)\end{array}$ \\
\hline Loss & $\begin{array}{l}0.219 * \\
(1.762)\end{array}$ & $\begin{array}{l}0.224^{*} \\
(1.808)\end{array}$ & $\begin{array}{l}0.257 * * \\
(2.057)\end{array}$ & $\begin{array}{l}0.221 * \\
(1.775)\end{array}$ & $\begin{array}{l}0.210^{*} \\
(1.690)\end{array}$ \\
\hline Client Size & $\begin{array}{l}0.057 * \\
(1.812)\end{array}$ & $\begin{array}{l}0.057 * \\
(1.786)\end{array}$ & $\begin{array}{c}0.057 * \\
(1.766)\end{array}$ & $\begin{array}{l}0.056^{*} \\
(1.761)\end{array}$ & $\begin{array}{l}0.057 * \\
(1.781)\end{array}$ \\
\hline $\mathrm{CFO}$ & $\begin{array}{c}0.103 \\
(0.254)\end{array}$ & $\begin{array}{c}0.176 \\
(0.432)\end{array}$ & $\begin{array}{c}0.117 \\
(0.286)\end{array}$ & $\begin{array}{c}0.168 \\
(0.410)\end{array}$ & $\begin{array}{c}0.145 \\
(0.356)\end{array}$ \\
\hline Debt & $\begin{array}{c}0.633 * * * \\
(2.855)\end{array}$ & $\begin{array}{c}0.642 * * * \\
(2.926)\end{array}$ & $\begin{array}{c}0.639 * * * \\
(2.895)\end{array}$ & $\begin{array}{c}0.678 * * * \\
(3.060)\end{array}$ & $\begin{array}{c}0.671 * * * \\
(3.031)\end{array}$ \\
\hline Revenue Growth & $\begin{array}{c}0.024 \\
(0.147)\end{array}$ & $\begin{array}{c}0.019 \\
(0.117)\end{array}$ & $\begin{array}{c}0.049 \\
(0.302)\end{array}$ & $\begin{array}{c}0.028 \\
(0.172)\end{array}$ & $\begin{array}{c}0.022 \\
(0.133)\end{array}$ \\
\hline Going Concern & $\begin{array}{c}-0.825 \\
(-1.526)\end{array}$ & $\begin{array}{c}-0.827 \\
(-1.521)\end{array}$ & $\begin{array}{c}-0.897 \\
(-1.633)\end{array}$ & $\begin{array}{c}-0.812 \\
(-1.502)\end{array}$ & $\begin{array}{c}-0.799 \\
(-1.485)\end{array}$ \\
\hline Tenure & $\begin{array}{c}-0.007 \\
(-0.540)\end{array}$ & $\begin{array}{c}-0.006 \\
(-0.498)\end{array}$ & $\begin{array}{c}-0.008 \\
(-0.586)\end{array}$ & $\begin{array}{c}-0.005 \\
(-0.396)\end{array}$ & $\begin{array}{c}-0.005 \\
(-0.423)\end{array}$ \\
\hline Revenue SD & $\begin{array}{c}0.076 \\
(0.233)\end{array}$ & $\begin{array}{c}0.078 \\
(0.241)\end{array}$ & $\begin{array}{c}0.125 \\
(0.396)\end{array}$ & $\begin{array}{c}0.092 \\
(0.287)\end{array}$ & $\begin{array}{c}0.076 \\
(0.234)\end{array}$ \\
\hline CFO SD & $\begin{array}{l}-1.588^{*} \\
(-1.929)\end{array}$ & $\begin{array}{l}-1.516^{*} \\
(-1.841)\end{array}$ & $\begin{array}{l}-1.466^{*} \\
(-1.822)\end{array}$ & $\begin{array}{l}-1.495^{*} \\
(-1.824)\end{array}$ & $\begin{array}{l}-1.542^{*} \\
(-1.867)\end{array}$ \\
\hline Restatement $_{\mathrm{t}-1}$ & $\begin{array}{l}3.127 * * * \\
(30.934)\end{array}$ & $\begin{array}{c}3.130 * * * \\
(30.913)\end{array}$ & $\begin{array}{c}3.094 * * * \\
(30.133)\end{array}$ & $\begin{array}{c}3.127 * * * \\
(30.919)\end{array}$ & $\begin{array}{c}3.132 * * * \\
(31.091)\end{array}$ \\
\hline Constant & $\begin{array}{l}-1.152 \\
(-1.263)\end{array}$ & $\begin{array}{l}-1.422 \\
(-1.587)\end{array}$ & $\begin{array}{c}-1.415 \\
(-1.519)\end{array}$ & $\begin{array}{l}-1.720 * \\
(-1.921)\end{array}$ & $\begin{array}{c}-1.461 \\
(-1.643)\end{array}$ \\
\hline Year Fixed & Yes & Yes & Yes & Yes & Yes \\
\hline Industry Fixed & Yes & Yes & Yes & Yes & Yes \\
\hline $\mathrm{N}$ & 7,388 & 7,388 & 7,388 & 7,388 & 7,388 \\
\hline Adj $R^{2}$ & 0.291 & 0.290 & 0.294 & 0.288 & 0.288 \\
\hline
\end{tabular}


Table 7 Continued

Panel C: Auditor Skill Sets and Audit Pricing

\begin{tabular}{|c|c|c|c|c|c|}
\hline & $(1)$ & (2) & (3) & (4) & $(5)$ \\
\hline Office \#(Total Skill) & $\begin{array}{c}-0.003 * * * \\
(-2.727)\end{array}$ & & & & \\
\hline Office \#(Cognitive Skill) & & $\begin{array}{c}-0.021 * * * \\
(-2.824)\end{array}$ & & & \\
\hline Office \#(Social Skill) & & & $\begin{array}{c}-0.001 \\
(-0.240)\end{array}$ & & \\
\hline Office \#(Financial Skill) & & & & $\begin{array}{c}-0.001 \\
(-0.391)\end{array}$ & \\
\hline Office \#(IT Skill) & & & & & $\begin{array}{c}-0.008 * * \\
(-2.313)\end{array}$ \\
\hline Office Size & $\begin{array}{c}0.024 * * * \\
(6.020)\end{array}$ & $\begin{array}{c}0.025 * * * \\
(6.058)\end{array}$ & $\begin{array}{c}0.024 * * * \\
(5.939)\end{array}$ & $\begin{array}{c}0.024 * * * \\
(5.947)\end{array}$ & $\begin{array}{c}0.024 * * * \\
(5.798)\end{array}$ \\
\hline Big4 & $\begin{array}{c}0.011 \\
(0.607)\end{array}$ & $\begin{array}{c}0.010 \\
(0.559)\end{array}$ & $\begin{array}{c}0.017 \\
(0.920)\end{array}$ & $\begin{array}{c}0.016 \\
(0.869)\end{array}$ & $\begin{array}{c}0.016 \\
(0.871)\end{array}$ \\
\hline Industry Leader & $\begin{array}{c}0.041 * * * \\
(5.105)\end{array}$ & $\begin{array}{c}0.041 * * * \\
(5.203)\end{array}$ & $\begin{array}{c}0.042^{* * *} * \\
(5.319)\end{array}$ & $\begin{array}{c}0.042 * * * \\
(5.322)\end{array}$ & $\begin{array}{c}0.041 * * * \\
(5.138)\end{array}$ \\
\hline Loss & $\begin{array}{c}0.034 * * * \\
(3.254)\end{array}$ & $\begin{array}{c}0.035^{* * *} \\
(3.268)\end{array}$ & $\begin{array}{c}0.035^{* * *} * \\
(3.274)\end{array}$ & $\begin{array}{c}0.035^{* * *} \\
(3.268)\end{array}$ & $\begin{array}{c}0.034^{* * *} \\
(3.183)\end{array}$ \\
\hline Client Size & $\begin{array}{c}0.126^{* * * *} \\
(19.368)\end{array}$ & $\begin{array}{c}0.126 * * * \\
(19.347)\end{array}$ & $\begin{array}{c}0.126^{* * *} \\
(19.434)\end{array}$ & $\begin{array}{c}0.126^{* * *} * \\
(19.448)\end{array}$ & $\begin{array}{c}0.126^{* * *} * \\
(19.387)\end{array}$ \\
\hline $\mathrm{CFO}$ & $\begin{array}{c}-0.050 \\
(-1.217)\end{array}$ & $\begin{array}{c}-0.048 \\
(-1.170)\end{array}$ & $\begin{array}{c}-0.048 \\
(-1.187)\end{array}$ & $\begin{array}{c}-0.048 \\
(-1.185)\end{array}$ & $\begin{array}{c}-0.049 \\
(-1.200)\end{array}$ \\
\hline Debt & $\begin{array}{c}-0.018 \\
(-0.875)\end{array}$ & $\begin{array}{c}-0.018 \\
(-0.871)\end{array}$ & $\begin{array}{c}-0.018 \\
(-0.831)\end{array}$ & $\begin{array}{c}-0.018 \\
(-0.833)\end{array}$ & $\begin{array}{c}-0.017 \\
(-0.823)\end{array}$ \\
\hline Revenue Growth & $\begin{array}{c}0.085 * * * \\
(5.022)\end{array}$ & $\begin{array}{c}0.085 * * * \\
(4.996)\end{array}$ & $\begin{array}{c}0.085 * * * \\
(4.999)\end{array}$ & $\begin{array}{c}0.085^{* * *} * \\
(5.003)\end{array}$ & $\begin{array}{c}0.085^{* * *} * \\
(4.979)\end{array}$ \\
\hline Going Concern & $\begin{array}{c}-0.007 \\
(-0.249)\end{array}$ & $\begin{array}{c}-0.007 \\
(-0.235)\end{array}$ & $\begin{array}{c}-0.007 \\
(-0.240)\end{array}$ & $\begin{array}{c}-0.007 \\
(-0.236)\end{array}$ & $\begin{array}{c}-0.005 \\
(-0.180)\end{array}$ \\
\hline Tenure & $\begin{array}{c}-0.003 * * * \\
(-2.626)\end{array}$ & $\begin{array}{c}-0.003 * * * \\
(-2.608)\end{array}$ & $\begin{array}{c}-0.003 * * * \\
(-2.581)\end{array}$ & $\begin{array}{c}-0.003 * * \\
(-2.569)\end{array}$ & $\begin{array}{c}-0.003 * * * \\
(-2.636)\end{array}$ \\
\hline Revenue SD & $\begin{array}{c}0.093 * * * \\
(2.657)\end{array}$ & $\begin{array}{c}0.094 * * * \\
(2.682)\end{array}$ & $\begin{array}{c}0.093 * * * \\
(2.663)\end{array}$ & $\begin{array}{c}0.093 * * * \\
(2.659)\end{array}$ & $\begin{array}{c}0.093 * * * \\
(2.679)\end{array}$ \\
\hline CFO SD & $\begin{array}{c}0.106 \\
(1.211)\end{array}$ & $\begin{array}{c}0.106 \\
(1.211)\end{array}$ & $\begin{array}{c}0.109 \\
(1.251)\end{array}$ & $\begin{array}{c}0.108 \\
(1.241)\end{array}$ & $\begin{array}{c}0.103 \\
(1.182)\end{array}$ \\
\hline AudFee $_{t-1}$ & $\begin{array}{c}0.746^{* * * *} \\
(61.752)\end{array}$ & $\begin{array}{c}0.746 * * * \\
(61.675)\end{array}$ & $\begin{array}{c}0.746^{* * *} * \\
(61.743)\end{array}$ & $\begin{array}{c}0.746^{* * *} * \\
(61.875)\end{array}$ & $\begin{array}{c}0.746^{* * *} \\
(61.730)\end{array}$ \\
\hline Constant & $\begin{array}{c}2.344 * * * \\
(19.398)\end{array}$ & $\begin{array}{c}2.322 * * * \\
(19.367)\end{array}$ & $\begin{array}{c}2.311 * * * \\
(19.279)\end{array}$ & $\begin{array}{c}2.314 * * * \\
(19.158)\end{array}$ & $\begin{array}{c}2.330 * * * \\
(19.277)\end{array}$ \\
\hline Year Fixed & Yes & Yes & Yes & Yes & Yes \\
\hline Industry Fixed & Yes & Yes & Yes & Yes & Yes \\
\hline $\mathrm{N}$ & 7,479 & 7,479 & 7,479 & 7,479 & 7,479 \\
\hline $\operatorname{Adj} R^{2}$ & 0.927 & 0.927 & 0.927 & 0.927 & 0.927 \\
\hline
\end{tabular}

